Annales Geophysicae (2001) 19: 469-486 (C) European Geophysical Society 2001

\title{
Two case studies on the interaction of large-scale transport, mesoscale photochemistry, and boundary-layer processes on the lower tropospheric ozone dynamics in early spring
}

\author{
S. Brönnimann ${ }^{1}{ }^{*}$, F. C. Siegrist ${ }^{1}$, W. Eugster ${ }^{1}$, R. Cattin ${ }^{1}$, C. Sidle ${ }^{1}$, M. M. Hirschberg ${ }^{2}$, D. Schneiter ${ }^{3}$, S. Perego ${ }^{4}$, and \\ H. Wanner ${ }^{1}$ \\ ${ }^{1}$ Institute of Geography, University of Bern, Hallerstr. 12, CH-3012 Bern, Switzerland \\ ${ }^{2}$ Lehrstuhl für Bioklimatologie und Immissionsforschung, TU München, Am Hochanger 13, D-85354 \\ Freising-Weihenstephan, Germany \\ ${ }^{3}$ MeteoSwiss, Station aérologique, Les Invuardes, CH-1530 Payerne, Switzerland \\ ${ }^{4}$ IBM Switzerland, Altstetterstrasse 124, CH-8010 Zürich, Switzerland \\ * present affiliation: Lunar and Planetary Laboratory, University of Arizona, 1629 E. University Blvd., Tucson, \\ AR 85721-0092, USA
}

Received: 23 October 2000 - Revised: 7 March 2001 - Accepted: 15 March 2001

\begin{abstract}
The vertical distribution of ozone in the lower troposphere over the Swiss Plateau is investigated in detail for two episodes in early spring (February 1998 and March 1999). Profile measurements of boundary-layer ozone performed during two field campaigns with a tethered balloon sounding system and a kite are investigated using regular aerological and ozone soundings from a nearby site, measurements from monitoring stations at various altitudes, backward trajectories, and synoptic analyses of meteorological fields. Additionally, the effect of in situ photochemistry was estimated for one of the episodes employing the Metphomod Eulerian photochemical model. Although the meteorological situations were completely different, both cases had elevated layers with high ozone concentrations, which is not untypical for late winter and early spring. In the February episode, the highest ozone concentrations of 55 to $60 \mathrm{ppb}$, which were found at around $1100 \mathrm{~m}$ asl, were partly advected from Southern France, but a considerable contribution of in situ photochemistry is also predicted by the model. Below that elevation, the local chemical sinks and surface deposition probably overcompensated chemical production, and the vertical ozone distribution was governed by boundarylayer dynamics. In the March episode, the results suggest that ozone-rich air parcels, probably of stratospheric or upper tropospheric origin, were advected aloft the boundary layer on the Swiss Plateau.
\end{abstract}

Key words. Atmospheric composition and structure (pollution - urban and regional; troposphere - composition and

Correspondence to: S. Brönnimann (broenn@giub.unibe.ch) chemistry) - Meteorology and atmospheric dynamics (mesoscale meteorology)

\section{Introduction}

In recent years a number of studies have reported unusually high near-surface ozone concentrations in many regions of the northern mid-latitudes already in early spring (e.g. Wakamatsu et al., 1998; Brönnimann, 1999). Although the magnitude of these peaks is smaller than that of typical summer episodes, they may, nevertheless, be important for air quality issues, since they occur at a time of year where some receptors are more vulnerable (e.g. during leafing of trees). In Switzerland, the 1-hour air quality standard for ozone (120 $\mu \mathrm{g} \mathrm{m}^{-3}$ ) is sometimes already exceeded in February, and peaks $>100 \mathrm{ppb}$ have been observed in March (Brönnimann, 1999). The causes for these episodes are not clear.

A lot has been learned about lower tropospheric ozone from studying summer episodes. Ozone is created in the atmosphere as a by-product of oxidation processes and can persist and accumulate or be transported during special meteorological conditions. An insight into the complex interplay between chemical and transport processes has emerged as a result of many international programmes and projects that have been conducted in the last decade (see Solomon et al., 2000). One finding is that summertime ozone accumulation is a multi-scale phenomenon (Schere and Hidy, 2000; Wotawa and Kromp-Kolb, 2000).

The situation is different in spring, when the photo-oxidat- 
ion is much slower and hence, the chemical lifetimes of many substances are longer (Parrish et al., 1999; Monks, 2000). In addition, the dynamics of the lower troposphere and especially the planetary boundary layer is different than in summer. The vivid discussion on the origin of the spring ozone maximum in the annual cycle at certain locations (Monks, 2000), to which early ozone episodes contribute, also makes clear that our understanding of the processes governing the ozone variability in the lower troposphere is still limited. For example, relatively little is known about the photochemistry in late winter and spring (Parrish et al., 1999).

In this study, the variability of vertical ozone profiles in late winter and spring is discussed in detail for two contrasting episodes on the Swiss Plateau in February 1998 and in March 1999. Both episodes showed high ozone concentrations at some altitude above ground, yet both were completely different from a meteorological point of view. The goal of our study was to explain the following: why have high concentrations of ozone been observed at the corresponding altitudes, where has this ozone originally been formed, why has this not been observed at other altitudes, and which processes on which spatial scales were involved in shaping the profiles? Our study is based on tethersonde measurements from field campaigns embedded in an analysis of routine data. Further investigations are performed with the help of trajectory models and with a photochemical model.

\section{An overview of relevant processes}

Different processes are relevant for the vertical ozone distribution in the lower atmosphere at northern mid-latitudes. The large-scale processes include stratospheric intrusions (e.g. Schuepbach et al., 1999; Stohl and Trickl, 1999), large-scale transport (Jacob et al., 1999) and "slow chemistry" based on the oxidation of $\mathrm{CO}$ and $\mathrm{CH}_{4}$ (Crutzen et al., 1999). Due to mixing, dispersion, and chemical processing, air masses loose their original properties during the course of the transport, so that large-scale transport is not thought to be more than a "preconditioner" for high-ozone episodes. Yet, coherent large-scale transport of ozone from the boundary layer, or from stratospheric intrusions over distances of several thousand kilometres has been reported by Stohl and Trickl (1999).

Photochemical ozone formation on the regional scale and mesoscale transport are usually more important in determining high ozone episodes (e.g. Ryan et al., 1998). Chemical formation is most efficient close to emission sources, with more reactive hydrocarbons being oxidised and the ample supply of $\mathrm{NO}_{x}$ as catalysts (e.g. Jenkin and Clemitshaw, 2000). In addition to anthropogenic emissions, the regional biogenic emissions can contribute significantly in summer (Staffelbach and Neftel, 1997). Local to regional modifications of the large-scale flow can also be important. In a complex topography this can lead to the creation of elevated layers with enhanced ozone concentration, as studied, for example, in the Los Angeles basin (McElroy and Smith, 1993) and in the Lower Fraser Valley (McKendry et al., 1997; see also the review by McKendry and Lundgren, 2000). Low-Level Jets (LLJ) can promote downward transport of ozone from an elevated layer to the surface (Corsmeier et al., 1997; Ryan et al., 1998; see also Hidy, 2000). The effect of local flow modification on pollutant transport in complex terrain has been studied intensively within the TRACT project (Fiedler and Borrell, 2000; see also the special issue of Atmospheric Environment, Vol. 32, No. 7, 1998) and also within the POLLUMET project (see next section). For the Alps, the influence of typical mountain effects, such as Foehn and valley winds on the transport of ozone and precursors, was recognised some time ago (Whiteman, 2000). These processes were studied in the VOTALP project (see special issue of Atmospheric Environment, Vol. 34, No. 9, 2000, especially the contributions of Furger et al., Prévôt et al., Seibert et al., and Wotawa et al.). Furthermore, Schuepbach et al. (1999) demonstrated the possible importance of gravity wave breaking in the lee of the Alps for ozone transport from the free troposphere to the surface.

The local scale has an influence on turbulent mixing and boundary-layer processes as well as on surface deposition. In typical summer episodes, the mixing of the boundary layer in the morning efficiently disperses the pollutants emitted at the surface. Ozone formation takes place in the whole of the boundary layer, whereas the sink is mainly at the surface (deposition, chemical sinks, titration). This leads to the typical belly shaped vertical ozone profiles. During the night, ozone is efficiently depleted in the stable nocturnal surface layer, but to a much lesser extent in the so-called "residual layer", where some of the ozone is stored (Neu et al., 1994; for a climatological framework see Aneja et al., 2000). The mixing on the next morning leads to an increase in ozone concentration at the surface and to a decrease in the residual layer.

This is the inventory of processes with which one has to explain the variability of vertical ozone distribution in the lower troposphere in spring.

\section{The study area}

The Swiss Plateau is located between two mountain ranges (Fig. 1), the Jura mountains in the Northwest and the Alps in the Southeast. The topography displayed in Fig. 1 is the one used in the "Swiss Model", which was, among others, employed for trajectory calculation. The Swiss Plateau is a densely populated region comprising a large part of the economic activity of Switzerland. The location of the tethersoundings, Kerzersmoos ( $435 \mathrm{~m}$ asl), is a rural site in the central part of the Swiss Plateau ("Seeland"), a region with a rather flat topography and intensive agriculture (Eugster et al., 1998); for a detailed description, see Siegrist (in press). Important monitoring sites are located at Payerne ( $496 \mathrm{~m}$ asl, aerological soundings, meteorology and air pollution monitoring) on the Swiss Plateau, and Chaumont (1140 m asl, air pollution monitoring) on the first ridge of the Jura mountains.

The flow on the Swiss Plateau is channelled between the two mountain ranges, so that the winds are either from the 
Southwest or from the Northeast (denoted "Bise", Wanner and Furger, 1990). This channelling effect reaches up to around $3500 \mathrm{~m}$ asl. A jet is sometimes observed in the wind profile at Payerne at about $1000 \mathrm{~m}$ asl (Furger, 1990). At the surface, the Swiss Plateau receives cold air by drainage flows from the Alps as well as from the Jura mountains. Cold air layers can be very persistent in winter. In summer, the exchange with the alpine valleys is efficient and can amount to one-third of the volume of the boundary layer over the Swiss Plateau every day (Neininger and Dommen, 1996).

High ozone values occur on the Swiss Plateau each summer and have been investigated in various studies, especially in the POLLUMET project (Neininger and Dommen, 1996; Wanner et al., 1993; Prévôt, 1994; Dommen et al., 1995; 1999; see also the special issue of Meteorologische Zeitschrift, N. F. 2, August 1993). A statistical analysis of aerological soundings from Payerne showed that transport distances during summer smog episodes are normally only around 50 to $100 \mathrm{~km} /$ day at the surface and 150 to 200 $\mathrm{km} /$ day at $1000 \mathrm{~m}$ asl, with somewhat higher values for the residual layer during the night (Jeannet et al., 1996). Hence, a large fraction (around $20 \mathrm{ppb}$ ) of the ozone peaks observed on the Swiss Plateau during summer episodes must be produced in situ over the Swiss Plateau (Neininger and Dommen, 1996), as was also supported by experimental (Künzle and Neu, 1994) and model studies (Dommen et al., 1995; Perego, 1999). It was shown that ozone formation in summer on the rural Swiss Plateau is mainly $\mathrm{NO}_{x}$ limited (Dommen et al., 1995). Plumes of cities, especially Zurich, were also identified to influence ozone on the Swiss Plateau (Dommen et al., 1999). The monitoring of time series revealed that ozone episodes frequently occur already in early spring at some elevation over the Swiss Plateau (Brönnimann, 1999).

The Seeland was a core region within the POLLUMET project with detailed chemical measurements on Mount Vully and tethered balloon soundings. With these data, the question of $\mathrm{NO}_{x}$ or VOC limitation was addressed and typical concentration ranges for many trace species were determined. Trajectory analyses suggested that the origin of air masses is important in this region, especially when air masses have passed over the urban region of Lyon (Prévôt, 1994).

The Swiss Plateau is a suitable area for detailed case studies. It can be considered a well investigated region with respect to air chemistry in a topographical setting of intermediate complexity. The area under investigation is usually referred to as rural, although the Swiss Plateau, as a whole, is relatively densely populated.

\section{Data and Methods}

This study makes use of many data sets and involves the application of several computer models. This section provides the relevant references for data sets, data quality, models, previous model applications, and validations.

The tethered balloon system from Atmospheric Instrumentation Research, Inc. (A. I. R., Boulder, CO, USA) consists

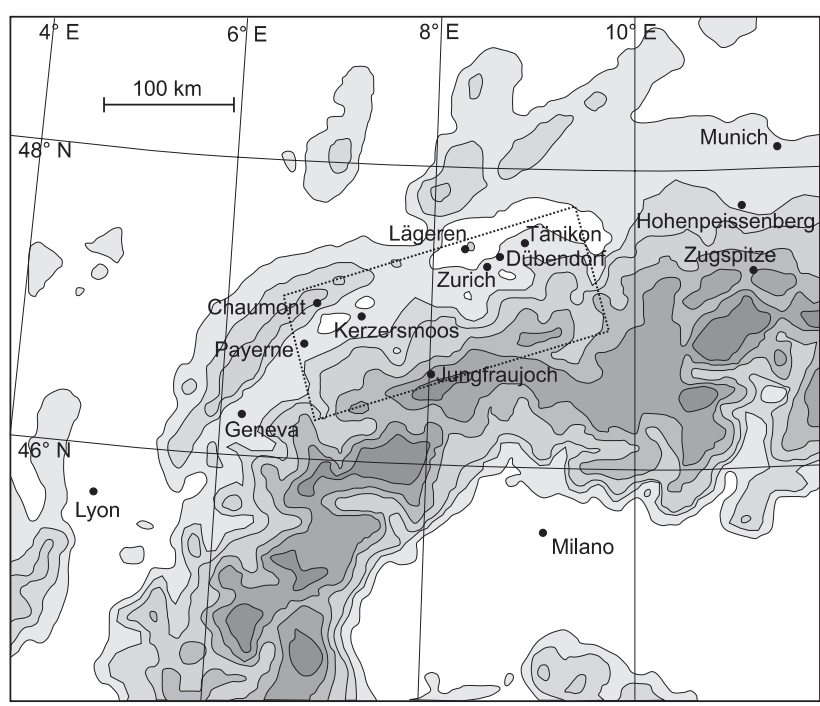

Fig. 1. Map of the study area with the locations of all measurement sites. The rectangle indicates the domain considered for photochemical modeling. Shaded areas give the topography from the Swiss Model (SM). Contour lines are drawn at 500, 750, 1000, 1500, 2000 and $3000 \mathrm{~m}$ asl.

of a $57 \mathrm{~m}^{3}$ helium-filled balloon on a $1800 \mathrm{~m}$ tether, a KI based ozone sonde OZ-3A-T (Baumbach et al., 1993), and a meteorological TS-5A-SEN (A. I. R.) sonde for temperature, relative humidity, pressure, wind speed and direction. Ozone soundings usually show somewhat higher values during descent than during ascent, which could be due to time lags and to decreasing voltage of the battery. Ascents are generally considered to be more reliable than descents.

Aerological soundings performed at Payerne include wind profiles every 6 hours, meteorological soundings every 12 hours (SRS-400 sonde, Richner and von Hünerbein, 1999) and ozone soundings three times per week (BM sonde, Hoegger et al., 1999; Stübi et al., 1999; 2000). Ozone sonde measurements in the lower troposphere should be considered as less accurate than surface measurements, but the shape of the profiles should be reliable.

Station measurements of chemical and meteorological parameters for Payerne, Lägeren, Chaumont, Rigi, Tänikon, Davos, and Jungfraujoch were taken from the Swiss air quality monitoring network NABEL (EMPA, 1994). Meteorological data from Payerne, Tänikon, and Jungfraujoch were provided by MeteoSwiss. CO data from Jungfraujoch are from EMPA (Swiss Federal Laboratories for Materials Testing and Research, Dübendorf). In addition, station measurements of ozone and humidity from Zugspitze were provided by IFU (Fraunhofer-Institut für Atmosphärische Umweltforschung, Garmisch-Partenkirchen).

Three-dimensional backward trajectories were calculated with three models and different meteorological fields representing different scales. We used the HYSPLIT-4 model from NOAA (Draxler and Hess, 1997, 1998) in conjunction with FNL archived meteorological data (Stunder, 1997). 

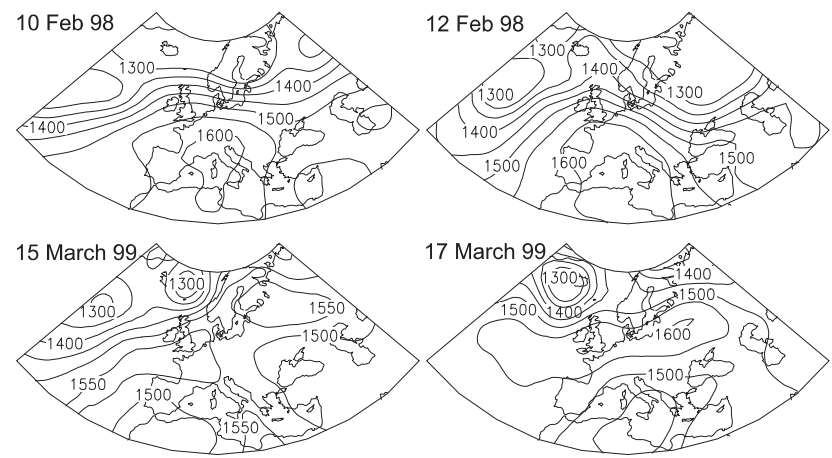

Fig. 2. $850 \mathrm{hPa}$ geopotential height field over Europe on 10 and 12 February 1998 (top) and 15 and 17 March 1999 (bottom), at 12 UTC. Contour lines are in units of geopotential meters.

The FLEXTRA model Version 1 (Stohl et al., 1995) was used together with wind fields from the ECMWF T213-L31 data set (ECMWF, 1994), interpolated to a $0.5^{\circ} \times 0.5^{\circ}$ grid with 3-hourly resolution. Finally, we also used backward trajectories calculated with the DWD trajectory model TRAJEK (Fay et al., 1994) based on the meteorological HRM/SM forecast model (High resolution model/Swiss Model, Schubiger and DeMorsier, 1992), which has a resolution of $14 \times$ $14 \mathrm{~km}^{2}$ and an appropriate orography (Fig. 1).

Numerical modelling was performed with the Metphomod model (Perego, 1999), a three-dimensional Eulerian photochemical model for the simulation of summer smog. The model includes a dynamical meteorological model, a soil module, and a solver for gas phase chemistry. Here we use the updated version 2.1, which includes a two-stream radiation module (based on the TUV model, Madronich et al., 1997) for calculating photolysis rates. More information about this model version can be found on the website indicated at the end of this article. Synoptic and meteorological analysis was performed with NCEP/NCAR reanalysis data (Kalnay et al., 1996) on a $2.5^{\circ} \times 2.5^{\circ}$ grid. Additionally, Meteosat water vapour images (provided by EUMETSAT) and total ozone data (TOMS version 7) from Earth Probe (McPeters et al., 1996) were used.

\section{Results}

In this section observational data and model calculations for both case studies are presented in a descriptive manner, starting with the tethered balloon and kite soundings at Kerzersmoos and ending with a presentation of trajectories and large-scale flow conditions. A discussion for each of the case studies is given in Sect. 6.

\subsection{Tethered balloon and kite soundings}

\subsubsection{February 1998}

The field campaign in February 1998 (Cattin, 1998) took place during a late winter high pressure episode. Air tem- peratures were relatively high, i.e. around $12{ }^{\circ} \mathrm{C}$ in the afternoon, but the soil was still around $0{ }^{\circ} \mathrm{C}$. The winds at the surface were weak during most of the campaign, mainly from the Southwest. Figure 2 shows the geopotential height at the $850 \mathrm{hPa}$ level on 10 and 12 February. Switzerland was slightly north of the centre of a high-pressure system, which moved slowly to the West during the episode. The campaign began on 10 February, in the evening, and lasted until the early afternoon of 12 February. A total of 25 soundings were performed. Since the wind speed was relatively high at around $900 \mathrm{~m}$ above ground, the balloon could not always penetrate into the layer aloft.

The data are displayed in Fig. 3a. The time-height cross sections of virtual potential temperature, $\theta_{v}$, show a fairly stable atmosphere. Some mixing is indicated for the afternoons of 11 and 12 February, but the mixing layer, derived from $\theta_{v}$, remained shallow, around 300 to $400 \mathrm{~m}$ deep. The water vapour mixing ratio, $r$, was relatively high, up to around $500 \mathrm{~m}$ above ground, but decreased aloft to rather low values. The boundary between the moist and the dry air was not the same as the estimated mixing height.

The amplitude of the diurnal ozone cycle was large at the surface. Ozone concentrations were practically zero at night, when a stable surface layer is clearly visible in the timeheight cross section of $\theta_{v}$. During the day, ozone concentrations at the surface increased to around $35 \mathrm{ppb}$. At about $1000 \mathrm{~m}$ asl, ozone concentrations, at all times, were considerably higher than at the surface. They were around 40 to $50 \mathrm{ppb}$ and reached a maximum of $55 \mathrm{ppb}$, which is high for this time of the year, on the afternoon of 11 February at 900 $\mathrm{m}$ asl.

\subsubsection{March 1999}

The second campaign in March 1999 (Cattin, 1999) started at the end of a short and moderate early spring ozone episode. Compared to the February campaign, the pressure distribution was rather flat in the beginning. During the following days, a high pressure ridge formed over Germany (Fig. 2), and Switzerland was in an easterly flow. Wind speeds at the Kerzersmoos site began to increase during 16 March, making balloon soundings impossible. A kite was used instead of the tethered balloon during the day (marked with " $\mathrm{K}$ " in Fig. $3 \mathrm{~b}$ ), reaching altitudes of up to $1140 \mathrm{~m}$ asl. The winds further increased during the morning of 17 March. Three soundings were performed with the kite during that morning, with wind speeds reaching $20 \mathrm{~m} / \mathrm{s}$, until a wind gust destroyed the kite and the sonde. The time-height cross sections differ significantly from the ones of the February campaign; the soil was warmer and the boundary layer was well mixed. $\theta_{v}$ increased and decreased synchronously at all heights but, in total, experienced a cooling through the episode. The humidity was high, up to a height of around $1000 \mathrm{~m}$ asl. The nocturnal profiles show that the atmosphere was slightly stratified (i.e. stable) during the night from 15 to 16 March, but probably mixed during the night from 16 to 17 March.

Ozone levels were around $50 \mathrm{ppb}$ or higher at all altitudes 

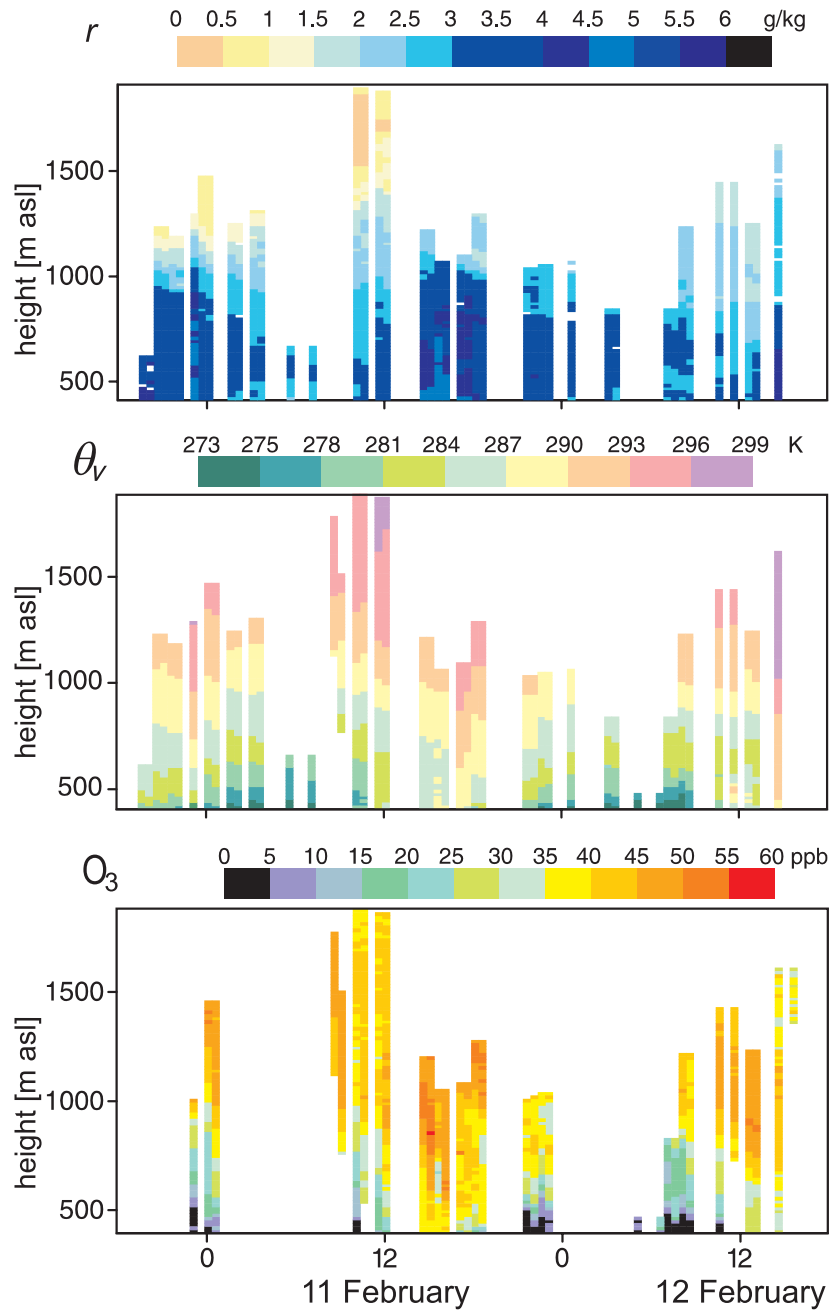

Fig. 3a. Time-height cross sections of virtual potential temperature, water vapour mixing ratio, and ozone concentrations as measured with tethered balloon during the February 1998 campaign. Every ascent or descent was attributed to a fixed half-hour interval.

on 16 March. The most interesting feature during the campaign were the high-ozone levels above $1000 \mathrm{~m}$ asl in the morning on 17 March. Winds were very strong throughout the sounded profile. There was a sharp increase of ozone, from about $30 \mathrm{ppb}$ at $750 \mathrm{~m}$ asl, to $60 \mathrm{ppb}$ at $1100 \mathrm{~m}$ asl, and a simultaneous decrease of the water vapour mixing ratio, $r$, from $3 \mathrm{~g} / \mathrm{kg}$ to values below $1 \mathrm{~g} / \mathrm{kg}$. The profiles of $\theta_{v}$ display a clear inversion at around $1000 \mathrm{~m}$ asl.

The data from the field campaigns reveal two contrasting episodes. In both cases, high ozone concentrations were found at some altitude above the surface. In the February 1998 campaign, ozone was not related to humidity and it remains unclear as to what extent different air masses were involved. In contrast, the March 1999 campaign clearly reveals the influence of several distinctly different air masses and, therefore, points to an important influence of transport processes.

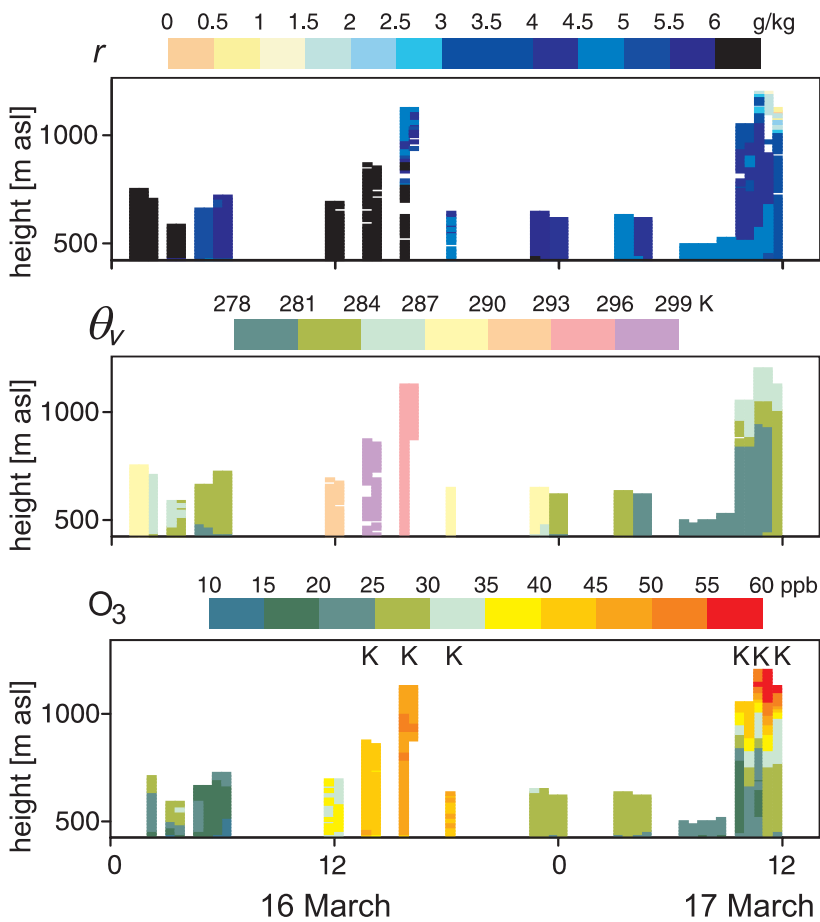

Fig. 3b. Time-height cross sections of virtual potential temperature, water vapour mixing ratio, and ozone concentrations measured with tethered balloon or kite (marked with K) during the March 1999 campaign.

\subsection{Aerological soundings and station data}

The data from the field campaigns give a detailed, yet incomplete picture of what was happening in the lower atmosphere over the Swiss Plateau during these days. With a coarser temporal resolution and on a somewhat larger scale, they can be complemented with aerological soundings from Payerne and suitable station data.

\subsubsection{February 1998}

Time-height cross sections based on Payerne soundings, up to a height of $3500 \mathrm{~m}$ asl, are displayed in Fig. 4 for the two case studies. Before the campaign, the general wind direction was from the Northeast. Then the winds changed to the Southwest for the period of the campaign. The wind speed cross section shows a jet-like behaviour during 11 February, just above the altitude of the adjacent Jura mountains. At the end of the campaign, the wind direction turned back to the Northeast.

The time-height cross section of $\theta_{v}$ in the February 1998 case reveals a relatively stable atmosphere. According to the difference in $\theta_{v}$ which was measured at screen-height $(2 \mathrm{~m})$, mixing remained shallow, at least around 13 CET. The atmosphere was relatively humid. The drier layer observed in Fig. 3a is also visible in the Payerne soundings. Temperatures were rather warm for the time of the year, although such warm "early spring" episodes are not uncommon for 

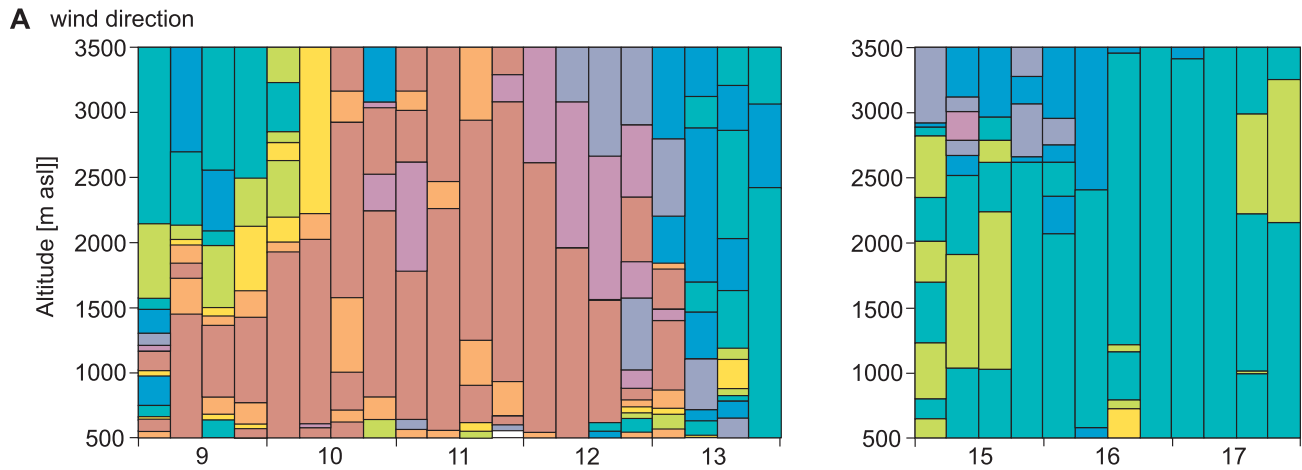

wind direction

B wind speed
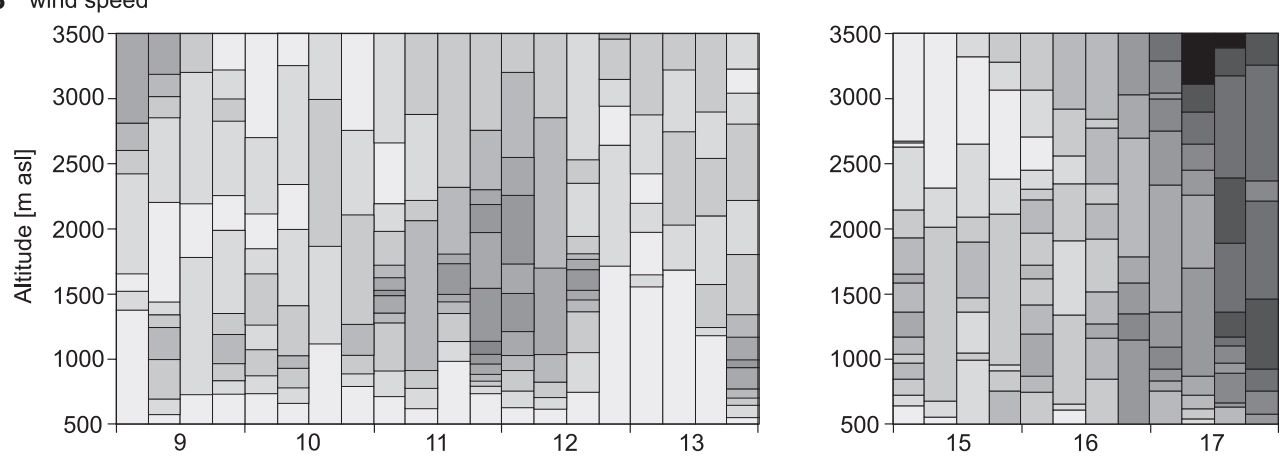

wind speed $[\mathrm{m} / \mathrm{s}]$

C mixing ratio, virtual potential temperature
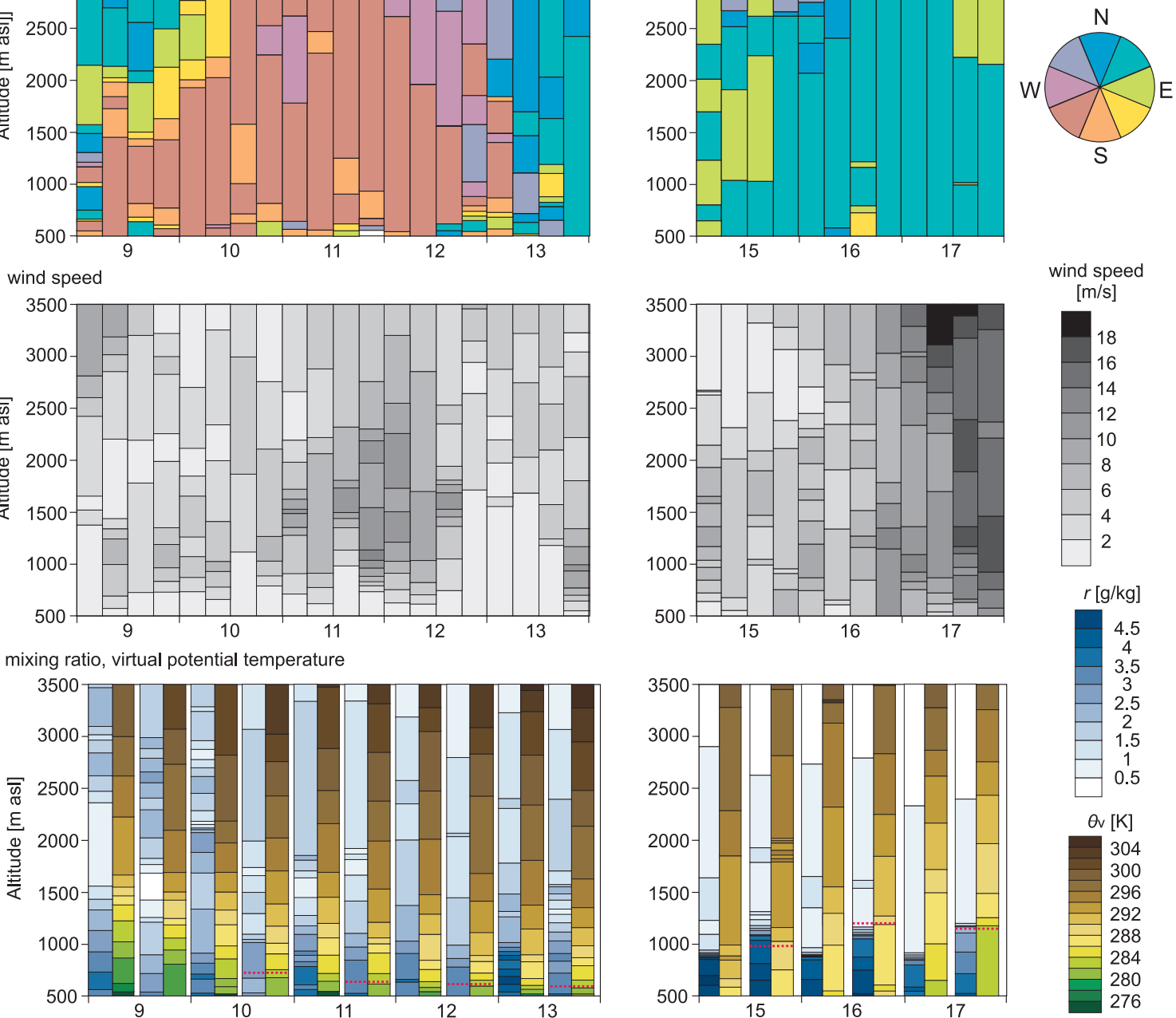

D ozone
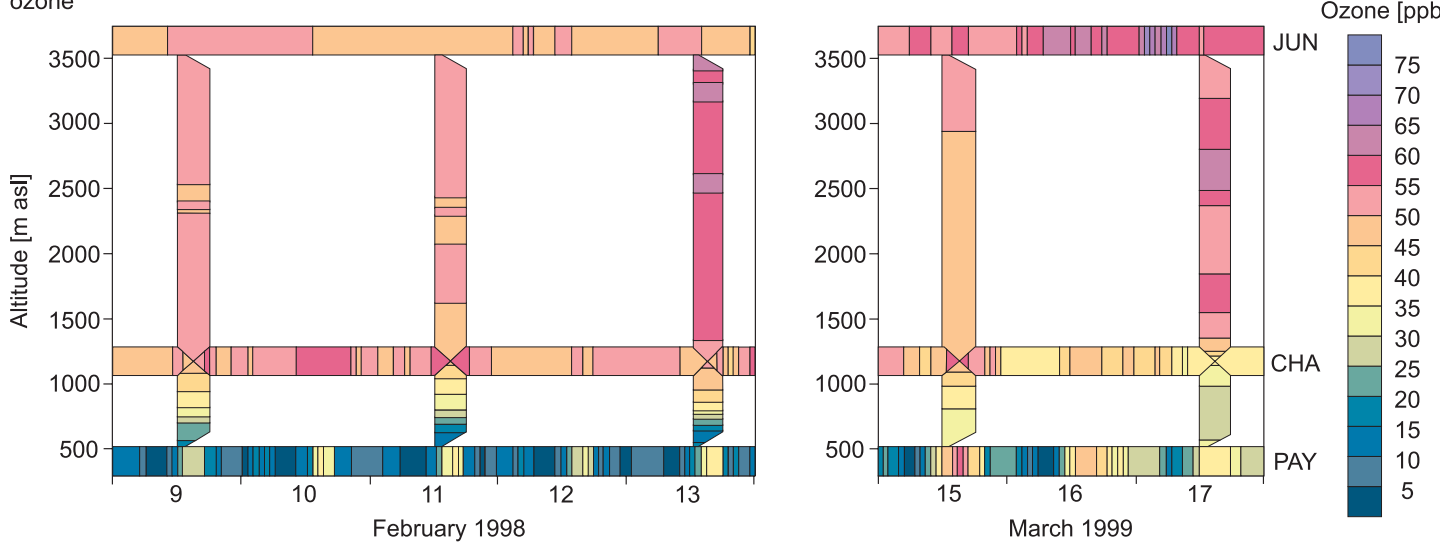

Fig. 4. Time-height cross sections of (a) wind direction, (b) wind speed, (c) water vapour mixing ratio (left bars) and virtual potential temperature (right bars) and (d) ozone concentrations. Left panels: February 1998 campaign, right panels: March 1999 campaign. The plots show measured data from aerological soundings from Payerne which were supplemented with hourly averaged station measurements of ozone concentration. No interpolation was done. Data were plotted as raw data and every measurement point was attributed to half of the layers above and below the measurement altitudes except for wind (layer below). Note that wind soundings were performed every 6 hours (00, 06, 12, 18 UTC), full meteorological soundings every 12 hours (00, 12 UTC) and ozone soundings every two days (12 UTC). The red solid lines in panels (c) give the estimated mixing height. 
Switzerland in February. A warming took place during the course of the episode.

Since the time resolution of ozone soundings was very coarse ( 2 days) when compared to the field campaigns, timeheight cross sections of ozone were complemented with station measurements (horizontal bars in Fig. 4) from Payerne, Chaumont, and Jungfraujoch (Fig. 1). Ozone concentrations at the surface and in the boundary layer, at noon, were very low, 30 to $35 \mathrm{ppb}$ at most, with a distinct diurnal cycle. In the evening, they rapidly sank to values below $5 \mathrm{ppb}$, indicating a strong local sink. Concentrations at Chaumont were higher than at Payerne at all times by at least $20 \mathrm{ppb}$. Combined with the strong gradient apparent in the Payerne ozone profiles at noon, this again indicates incomplete mixing. Ozone concentrations at Chaumont were between 45 and $60 \mathrm{ppb}$, with a diurnal cycle, and were higher at almost all times than at the high-alpine site Jungfraujoch.

\subsubsection{March 1999}

During the March 1999 campaign, winds were persistently from the Northeast ("Bise"). Wind speeds were moderate at the beginning, again with some jet-like features, then increased throughout the lower troposphere and reached $20 \mathrm{~m} / \mathrm{s}$ in the morning of 17 March.

Time-height cross sections of $\theta_{v}$ and $r$ in March 1999 reveal a well developed mixing layer. The mixing height, as estimated from the difference between $\theta_{v}$ and $\theta_{v}$ at the surface, corresponds well with the sharp gradient in the mixing ratio profiles. The atmosphere above was very dry, confirming that there must have been two different air masses.

In the time-height cross section of ozone for March 1999, the end of a short ozone episode is visible at Payerne and Chaumont, with peaks reaching $60 \mathrm{ppb}$ (the maximum at Chaumont on 14 March was $64 \mathrm{ppb}$ ). Ozone concentrations in Payerne showed a clear diurnal cycle. Nocturnal concentrations were almost zero during the first two nights (14/15 and 15/16 March), but somewhat higher during the night from 16 to 17 March. Daily peaks decreased from 56 ppb on 15 March to $30 \mathrm{ppb}$ on 17 March. The small difference in ozone concentrations between Chaumont and Payerne again points to good mixing during the day; this is also indicated by the Payerne ozone profiles. Ozone concentrations at Chaumont showed a clear diurnal cycle only on the first day (15 March), then the diurnal cycle became less clear and was absent on 17 March and concentrations strongly decreased. Payerne ozone soundings show an increase of ozone from 15 to 17 March in the free troposphere. On 17 March, two local maxima appeared at heights around 1700 and 2700 $\mathrm{m}$ asl.

At Jungfraujoch, ozone concentrations were clearly higher than at Chaumont, especially from 16 March onward. Most remarkably, two short peaks of 72 and $81 \mathrm{ppb}$ (half hour values) were observed during the night from 16 to 17 March. These sharp peaks were preceded by a smaller, smoother increase during 16 March. Figure 5 shows Jungfraujoch station measurements of $\mathrm{NO}, \mathrm{NO}_{2}, \mathrm{CO}, \mathrm{SO}_{2}$, relative humid-

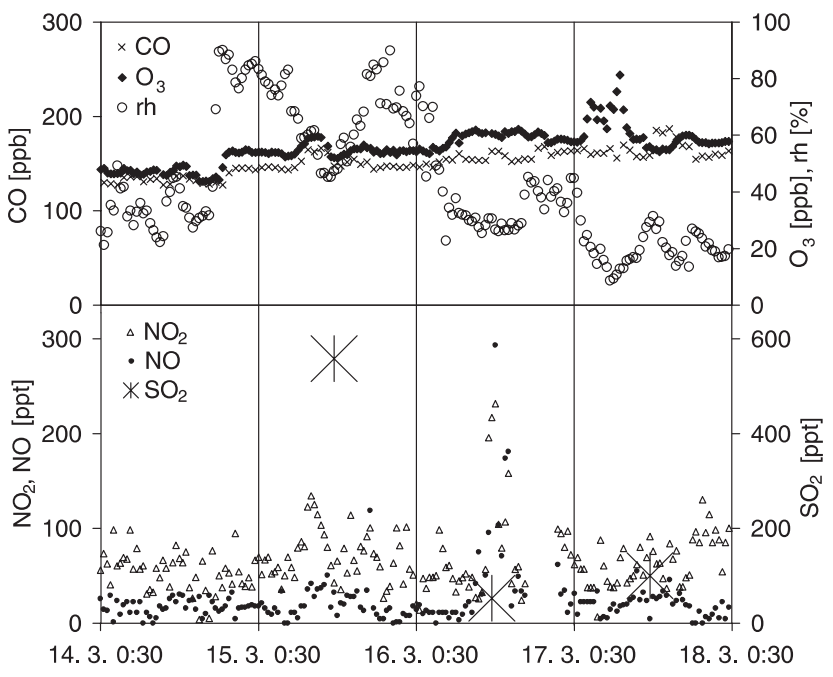

Fig. 5. Measurements of ozone, $\mathrm{NO}, \mathrm{NO}_{x}, \mathrm{SO}_{2}, \mathrm{CO}$, and relative humidity at Jungfraujoch from 14 to 17 March 1999. Note that $\mathrm{SO}_{2}$ data are daily average values.

ity, and ozone from 14 to 17 March. Different changes in air mass can be addressed within this time span. The high-ozone event during the morning of 17 March was accompanied by a sharp drop in humidity, to values below $10 \%$, with low $\mathrm{SO}_{2}$ concentrations and low $\mathrm{NO}_{x}$ levels of around 60 ppt. Little changes, however, were observed in $\mathrm{CO}$ concentrations.

The analysis of aerological soundings reveals additional features in both episodes. In February 1998, the high ozone levels at around $1200 \mathrm{~m}$ asl and the occurrence of a jet in the wind profile at the same height direct our focus towards this altitude. In March 1999, the data imply the picture of many changes, a sequence of different air masses and sharp spatial gradients of air mass properties. Ozone concentrations reached $81 \mathrm{ppb}$ at Jungfraujoch. The spiky character of the ozone peak and the low levels of humidity, $\mathrm{NO}_{x}$, and $\mathrm{SO}_{2}$ point to a stratospheric intrusion as a possible source. This hypothesis will be further discussed in Sect. 5.4.

\subsection{Mesoscale photochemical modelling}

The measured ozone profiles during the February 1998 episode bear many features in common with typical summertime ozone profiles, such as the diurnal cycles at all levels and the ozone maximum at some altitudes above the ground. Photochemistry is, therefore, considered as a possible driving factor. On the other hand, solar radiation is very low in mid-February and hence, photochemistry is only expected to proceed very slowly. The question of whether ozone can be formed photochemically in a sufficient amount, so early in the season as to explain these features, will be tackled in this section with the aid of the photochemical Metphomod model (Perego, 1999). 


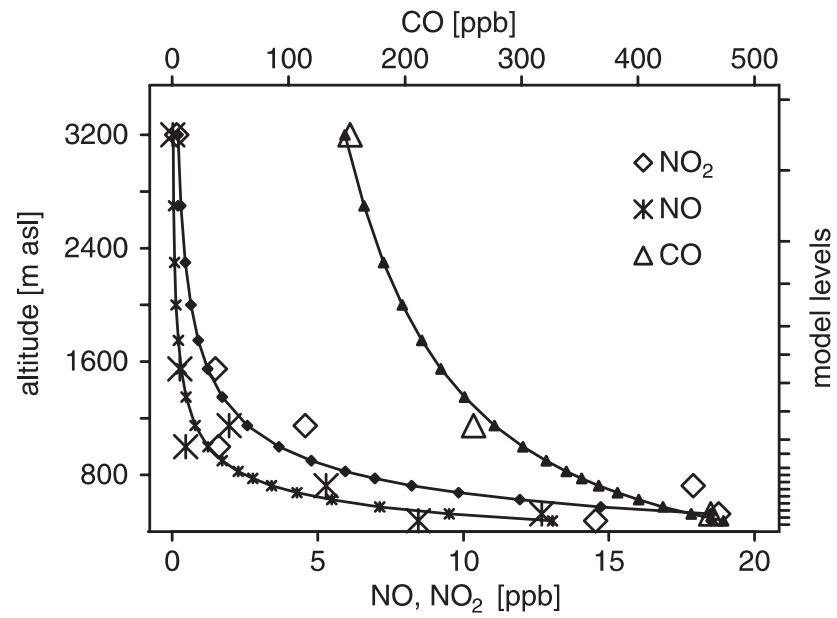

Fig. 6. Measurements of $\mathrm{NO}, \mathrm{NO}_{2}$ and $\mathrm{CO}$ at different sites on 9 February, 11 to 13 UTC, and initial values prescribed to the 18 levels of Metphomod by fitting a power law to the measured concentrations (the value in the lowest model layer was replaced with the value from the second lowest layer).

\subsubsection{Setup of the model experiment}

The square in Fig. 1 gives the model domain. It comprises a large part of the Swiss Plateau as well as the pre-alpine foothills and the first chain of the Alps. The model used a horizontal grid of $100 \times 45$ cells at a resolution of $2 \times 2 \mathrm{~km}^{2}$ with 18 vertical levels (Cartesian, see Fig. 6). A fixed time step of $10 \mathrm{~s}$ for meteorology and a variable one (1 to 120 s) for chemistry were chosen. The chemical RACM mechanism (Stockwell et al., 1997) was used. Quantum yields and absorption cross sections were taken from the RACM (Stockwell et al., 1997 and references therein; Frank Kirchner, personal communication, 2000), except for R1 to R3, which were taken from the TUV model (Madronich et al., 1997). The quantum yields for ozone photolysis were taken from Shetter et al. (1996). Total ozone was set to $400 \mathrm{DU}$, and radiation was calculated for every grid-point for every $120 \mathrm{~s}$.

The model had been developed for summer situations and was first used for the Swiss Plateau. For input and border data, we could partly rely on these data, which are described in Perego (1999). They include emissions from the detailed TRACT inventory (Kunz et al., 1995) as well as surface data. The soil properties had to be adapted to winter conditions. Soils were assumed to be water saturated in the Swiss Plateau and partially or fully snow covered at higher altitudes, depending on vegetation type and exposition. Since the model does not explicitly include snow layers, the effect of snow was achieved by adjusting the soil heat diffusivity and heat capacity, as well as the albedo and the fraction of plant cover.

The full input data set can be downloaded, together with the original summer input data and the model itself, from the website indicated at the end of this article. In the emission inventory, we scaled $\mathrm{NO}$ and $\mathrm{NO}_{2}$ emissions with a factor of
1.2 (accounting for domestic heating), and $\alpha$-pinene and Isoprene emissions with a factor of 0.2 (less biological activity). We did not change the aggregation factors for the RACM classes. The model was initialised on 9 February, 13 CET with ozone and meteorology from the Payerne sounding. For other substances we used station data from different altitudes from 12 to 14 CET (average). Distinct concentration minima were found for almost all substances and sites during this time, which points to some degree of mixing and, therefore, a better representativity of the surface measurements for a grid cell. For $\mathrm{NO}$ and $\mathrm{NO}_{2}$, we used data from Payerne, Tänikon, Lägeren, Rigi, Chaumont, Davos, and Jungfraujoch (Fig. 1); $\mathrm{CO}$ was available from Tänikon, Chaumont, and Jungfraujoch. A power law fitted to the station altitude provided the initialisation profiles with the exception of the surface layer, for which we used the same value as for the second layer (Fig. 6). $\mathrm{CH}_{4}$ was set to $1700 \mathrm{ppb}$ and PAN to $0.18 \mathrm{ppb}$, according to February measurements (Wunderli and Gehrig, 1991). For VOCs, data from Tänikon, a rural site on the Swiss Plateau, were aggregated into RACM classes following Stockwell et al. (1997) and references therein, using the same aggregation factors. Vertical profiles were obtained by scaling the fitted profile for $\mathrm{NO}$ (as a representative of shortlived species) to match the observations for ETH, ETE, HC3, HC5, HC8, OLT, TOL, and XYL in the second model layer (location of Tänikon).

The model was forced towards fixed values at the borders (border type "sponge"). For meteorological parameters and ozone, these values were taken from the soundings at Payerne at the main inflow border and were linearly interpolated with time. The model top (at $3450 \mathrm{~m}$ asl) was constrained with the geostrophic wind from the Payerne soundings. The initial data for $\mathrm{CH}_{4}$ and the $\mathrm{CO}$ profile were also used at the borders; all other substances were set to the average of the corresponding model level at the preceding time step.

The net chemical production of ozone was calculated with two approaches. Following an "Eulerian" framework, all concentration changes in a cell that occur due to chemical reactions (not due to mixing, dispersion, transport, or deposition) were calculated for each grid cell. This production rate includes the effect of titration and reformation of ozone from $\mathrm{NO}_{2}$. This is suitable for addressing the observed changes in the profile over Kerzersmoos, which is influenced by titration/reformation. It can also be used for budget calculations when integrated over the entire model and summed up over the entire time span.

In a "Pseudo-Lagrangian" framework we introduced a chemically inert tracer that was initialised to the current ozone field at a chosen time and then transported and deposited. The border data and deposition were the same as for ozone. With the field of the difference between the tracer and ozone, and with an additional tracer accounting for the residence time in the model, we could calculate an approximate net ozone production for an air parcel over short time periods. This production rate is not influenced by titration/reformation, as long as it occurs within the considered time span. The model was run for 100 hours until 13 Febru- 

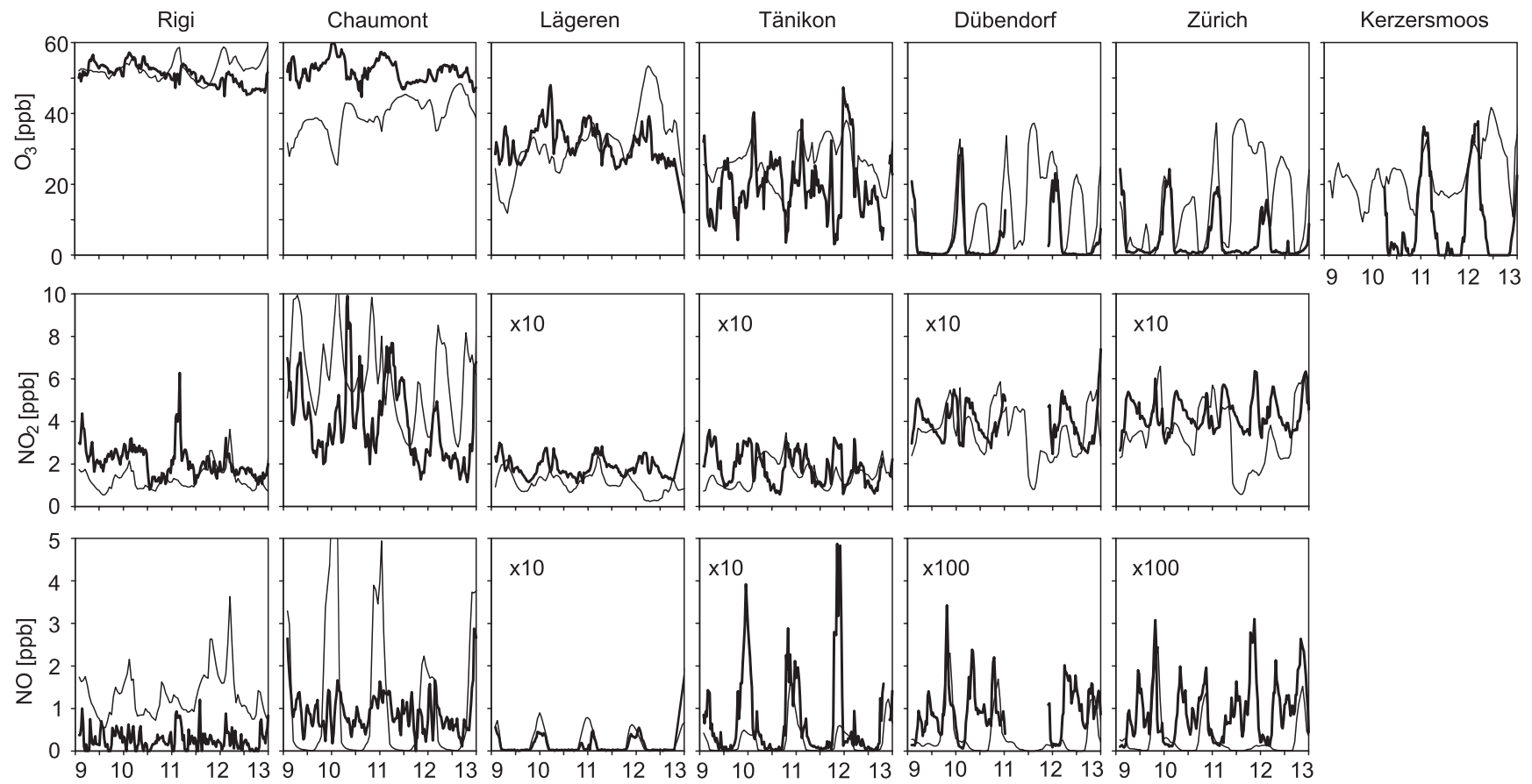

Fig. 7. Observed (thick lines) and modelled (thin lines) time series of $\mathrm{NO}, \mathrm{NO}_{2}$ and ozone at eight sites from 9 February, 12 UTC to 13 February, 12 UTC. For Lägeren, which is on a $45 \mathrm{~m}$ tower on a steep slope, the corresponding grid cell was too low, therefore, we used a point more to the east at correct elevation.

ary, 16 UTC (17 CET).

\subsubsection{Model validation}

We validated the model results by comparing station measurements of $\mathrm{NO}, \mathrm{NO}_{2}$, and $\mathrm{O}_{3}$ from several sites with modelled values for the corresponding grid cells (Fig. 7). This gives a useful indication whether the model captures the main characteristics of the spatio-temporal concentration variability. Note, however, that the model gridpoints represent grid cells of $2 \times 2 \mathrm{~km}^{2}$ with a height of $50 \mathrm{~m}$ or more, whereas the measurements very often are only locally representative. With respect to ozone, the agreement between model and measurement is very good for Rigi and reasonably good for Lägeren, Tänikon, and Kerzersmoos. The deviation at Chaumont ( 8 cells downwind of the border) is due to the border values which are too low. The nocturnal differences at Lägeren, Tänikon, and Kerzersmoos are due to stronger surface influences in the measurements ( 2 to $4 \mathrm{~m}$ above ground), as compared to the grid cell averages. This is probably also the main cause for the deviations found at the polluted sites, where the extremely high level of observed NO concentrations (up to $350 \mathrm{ppb}$ ) are not reproduced by the model. $\mathrm{NO}_{2}$ is well predicted at all sites. The decrease of $\mathrm{NO}_{2}$ and increase of ozone at all polluted sites on the evening of 11 February is produced by a jet-like wind gust in the model that hits the surface layer and leads to an exchange with the upper layers. This jet existed (Fig. 4), but in reality did not reach the surface. All together, it can be said that the model shows good agreement with station data and gives realistic results even after four days of simulation.

Figure 8 shows time-height cross sections of specific humidity, ozone, $\mathrm{NO}_{2}$, and the ozone production rate for the location of Kerzersmoos. The humidity profile shows the observed dry air layer between 1400 and $1700 \mathrm{~m}$ asl, and distinct humidity maxima close to the surface in the early afternoon. As in the measurements (Fig. 3a), a tongue of high ozone concentrations reaches down close to the surface during the afternoon of 11 February and less pronounced on 12 February. With respect to ozone, humidity and temperature (not shown), the agreement between the model results and the Kerzersmoos soundings is very good. $\mathrm{NO}_{2}$ exhibits rather high values in the boundary layer, around $5 \mathrm{ppb}$ or more. The diurnal cycle shows a morning peak that influences the whole boundary layer.

\subsubsection{Model results}

The bottom panel of Fig. 8 shows the "Eulerian" net chemical ozone production rate. The highest values of up to 5 $\mathrm{ppb} / \mathrm{h}$ are calculated after sunrise, between 8 and 9 CET at about $100 \mathrm{~m}$ above ground. They result from reformation of ozone titrated during the night. A second maximum appears in the early afternoon, and it is suggested that this is mainly due to photochemical production. This maximum was very pronounced on 11 February and less so on the other days. If the $\mathrm{O}_{3} / \mathrm{NO}_{z}$ ratio can also be used as a photochemical indicator in winter with the thresholds given in Sillman (1995), then ozone production at Kerzersmoos during the afternoon of 11 February was VOC sensitive $\left(\mathrm{O}_{3} / \mathrm{NO}_{z}<7\right)$, up to about 700 

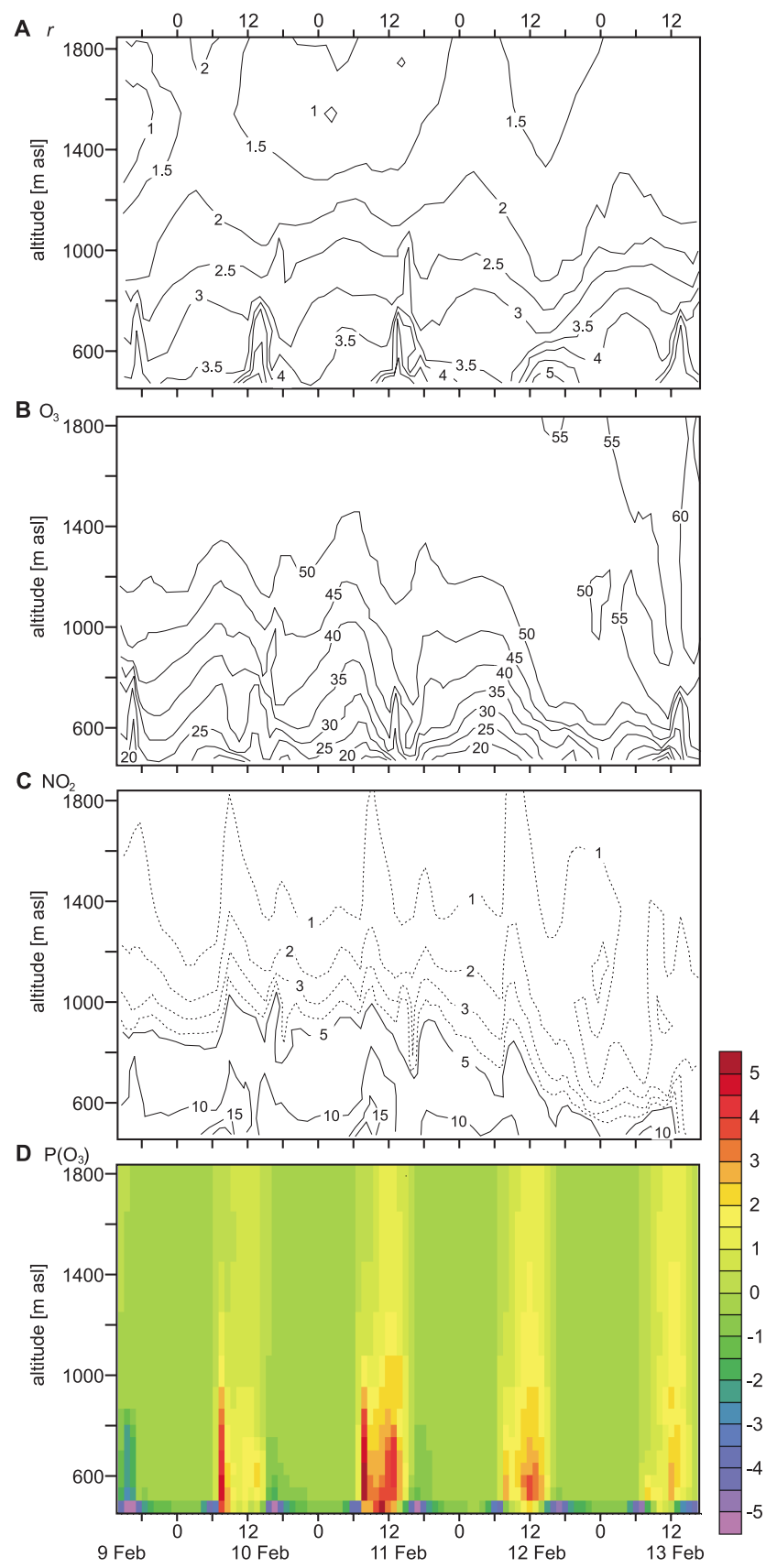

Fig. 8. Modelled time-height cross sections of (a) specific humidity [g/kg], (b) ozone [ppb], (c) $\mathrm{NO}_{2}$ [ppb], and (d) net chemical ozone production rate $[\mathrm{ppb} / \mathrm{h}]$ for the location of Kerzersmoos.

$\mathrm{m}$ asl and $\mathrm{NO}_{x}$ sensitive $\left(\mathrm{O}_{3} / \mathrm{NO}_{z}>10\right)$ above $1000 \mathrm{~m}$ asl. On the other afternoons, the $\mathrm{O}_{3} / \mathrm{NO}_{z}$ ratio was intermediate (between 7 and 10). A chemical sink reaching $-2 \mathrm{ppb} / \mathrm{h}$ in the lower boundary layer and $-6 \mathrm{ppb} / \mathrm{h}$ at the surface is predicted for the late afternoon and after sunset. On a molecule basis, summed up over three diurnal cycles (10 Feb, 6 CET to $13 \mathrm{Feb}, 6 \mathrm{CET}$ ), the surface layer over Kerzersmoos is a chemical sink that is compensated by chemical sources at an altitude of $600 \mathrm{~m}$ asl (i.e. within the lowest $150 \mathrm{~m}$ ). If deposition is also considered, then the column over Kerzersmoos is a net sink up to $1250 \mathrm{~m}$ asl. Over the whole model domain, sources and sinks balance below $1750 \mathrm{~m}$ asl and the model is a weak source. The predicted ozone field at the surface on 11 February, 6 CET is shown in Fig. 9a. Ozone concentrations are close to zero on the Swiss Plateau and at the bottom of alpine valleys, whereas higher concentrations are predicted at higher elevations. At $1000 \mathrm{~m}$ asl (Fig. 9b), there is little spatial variability; ozone concentrations are around 35 to $50 \mathrm{ppb}$. At $15 \mathrm{CET}$, surface level ozone concentrations (Fig. 9c) are around 20 to $40 \mathrm{ppb}$ on the Swiss Plateau and 50 to $60 \mathrm{ppb}$ at higher elevations. At $1000 \mathrm{~m}$ asl (Fig. 9d), concentrations between 45 and $55 \mathrm{ppb}$ are predicted. Figure $9 \mathrm{e}, \mathrm{f}$ show the approximate rate of ozone production during the last two hours (calculated in the "Pseudo-Lagrangian" framework) for each air parcel on 11 February, 15 CET. At the surface (Fig. 9e), air masses transported along the major traffic routes and over the cities on the Swiss Plateau are depleted in ozone at a rate of -2 to $-4 \mathrm{ppb} / \mathrm{h}$, whereas they are enriched at rates of 4 to $8 \mathrm{ppb} / \mathrm{h}$ in the lee of Zurich and Bern. Over large parts of the Swiss Plateau, ozone is produced at a rate of 1 to $4 \mathrm{ppb} / \mathrm{h}$. Distinct ozone production areas are found along the south slope of the Jura mountains. The corresponding field of the "Eulerian" production rate at noon (not shown) is mainly determined by small areas of heavy titration (up to $-30 \mathrm{ppb} / \mathrm{h}$ ) and reformation $(+15 \mathrm{ppb} / \mathrm{h}$ ) of ozone, but agrees with the 1 to $4 \mathrm{ppb} / \mathrm{h}$ obtained for rural areas (also over Kerzersmoos: see Fig. 8). Interestingly, the highest production rates in the "Pseudo-Lagrangian" framework of 8 or $9 \mathrm{ppb} / \mathrm{h}$ are found when the plume of Zurich was advected over snow surfaces with higher albedo, where $\mathrm{NO}_{2}$ photolysis was enhanced and a new photochemical equilibrium reached (this concerns some of the grid cells in Fig. 9e which are empty, i.e. lower than topography, in Fig. 9f). These production rates seem high, but they may be realistic. They reflect that temporary reversible phenomena are considered in our approach, only if they exceed the considered time scale of 2 hours. Note also that the early afternoon of 11 February represents the period of the highest ozone production during these four days and, therefore, has to be considered as an upper limit. In all, according to the RACM chemical mechanism, considerable ozone production already seems possible in late winter.

\subsection{Trajectory models and large-scale circulation}

The analysis of tether balloon and radio sonde data suggests an important role of transport processes. This section presents an analysis of backward trajectories for both case studies, as well as a study of the synoptic context and the large-scale circulation.

\subsubsection{Backward trajectories for February 1998}

In February 1998, the importance of transport is indicated from the coincidence of high ozone concentrations and a jet in the vertical profile of the wind speed at about $850 \mathrm{hPa}$. Less transport is expected (due to low wind speeds) above 
(a) Ozone concentration at the surface, 11 Feb 98, 6 CET

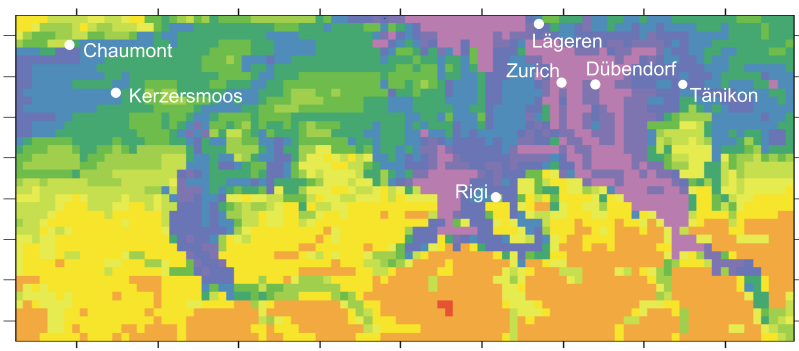

(c) Ozone concentration at the surface, 11 Feb 98, 15 CET

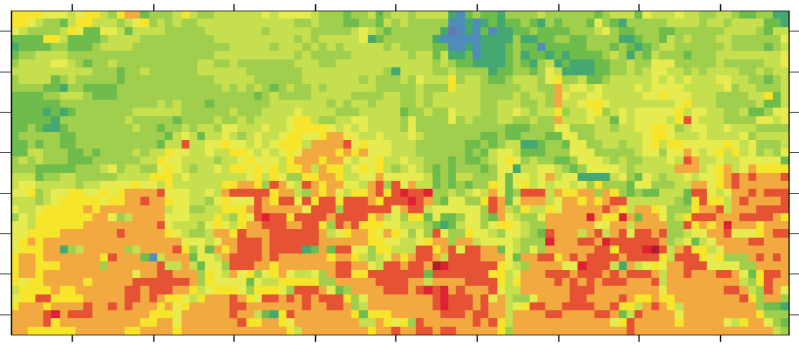

(e) Ozone production rate at the surface, 11 Feb 98, 13-15 CET

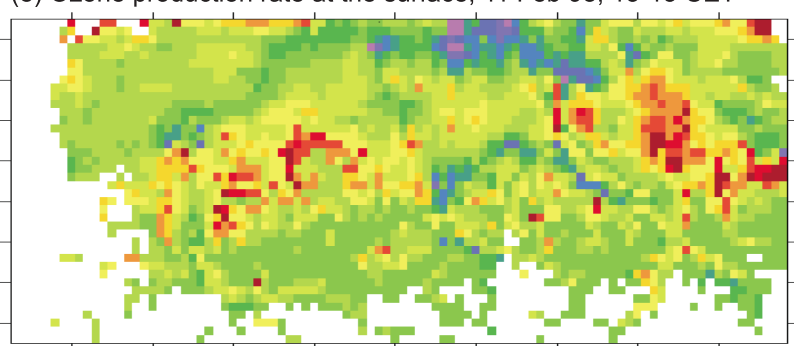

(b) Ozone concentration at $1000 \mathrm{~m}$ asl, 11 Feb 6 CET

[ppb]

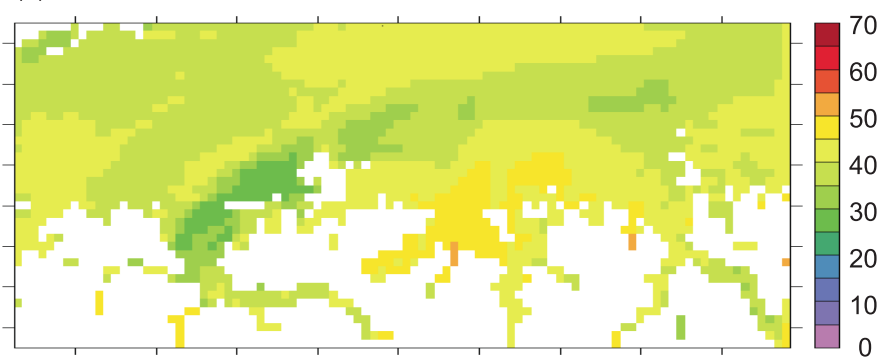

(d) Ozone concentration at $1000 \mathrm{~m}$ asl, $11 \mathrm{Feb} 98,15$ CET

[ppb]

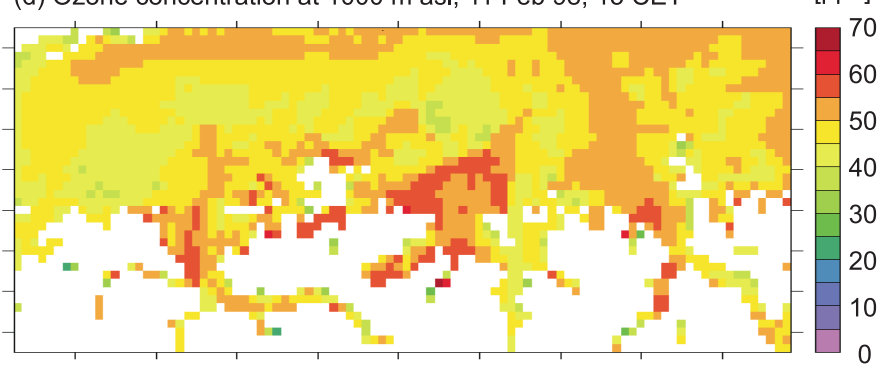

(f) Ozone production rate at $675 \mathrm{~m}$ asl, $11 \mathrm{Feb} 98,13$ to $15 \mathrm{CET} \quad$ [ppb/h]
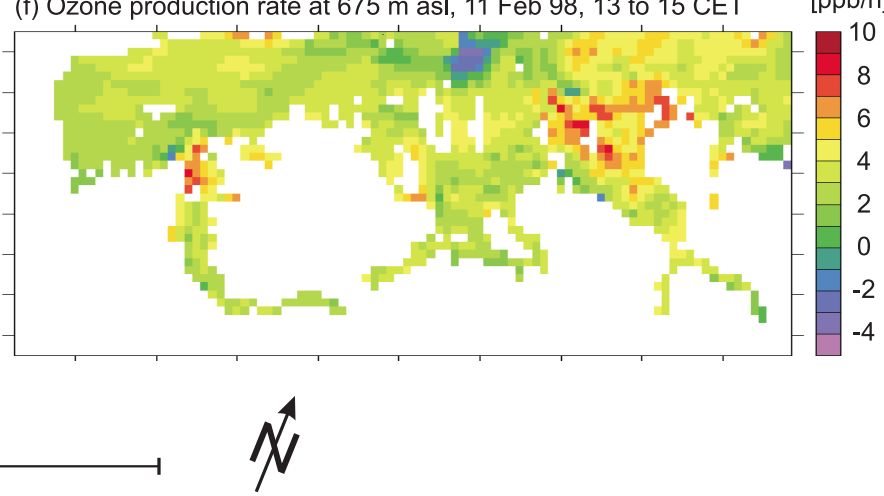

Fig. 9. Ozone concentration fields modelled by Metphomod for 11 February, 6 CET at the surface (a) and at $1000 \mathrm{~m}$ asl (b), and on 11 February 15 CET at the surface (c) and at $1000 \mathrm{~m}$ asl (d). Average ozone production rate in the "Pseudo-Lagrangian" framework for the last 2 hours at the surface (e) and at $675 \mathrm{~m}$ asl (f), for air parcels at 11 February 16 CET. The outermost two grid cells on all sides were deleted in all charts. White spots are below topography.

and below this layer. We calculated 72 hours backward trajectories (FLEXTRA/ECMWF), arriving at different heights over Kerzersmoos and eight surrounding points $\left(7.17 \pm 0.25^{\circ}\right.$ E, 47.00 $\pm 0.25^{\circ} \mathrm{N}$ ) in February 1998.

Figure 10 shows the trajectories arriving at $850 \mathrm{hPa}$. Since there was relatively little scatter within the ensembles, only the central trajectories are displayed. According to these results, air masses originated from the middle troposphere over Germany/North Sea, from where they descended to $700 \mathrm{hPa}$ after having crossed the Alps and further down to $850 \mathrm{hPa}$ over Italy. The trajectories had a pronounced anticyclonic shape; they performed a loop west of Sardegna and flowed north-eastward towards the Swiss Plateau. Trajectories later during the episode were slower than the earlier ones, but followed almost the same path. We consider it plausible that the air masses observed at around $1000 \mathrm{~m}$ asl and higher over Kerzersmoos originated from the Mediterranean area and were advected over Southern France.

\subsubsection{Backward trajectories for March 1999}

For the March episode, HYSPLIT/FNL and DWD/SM backward trajectories were used. HYSPLIT/FNL 96 hrs backward trajectories for different arrival heights and times for Kerzersmoos are displayed in Fig. 11. As expected from the observations, all trajectories arrive from the Northeast. On 16 March, trajectories have an anticyclonic shape and the origin is South of Greenland (for air masses arriving at 1500 $\mathrm{m}$ above ground), Gulf of Biscay (500 m) and Southern Germany $(100 \mathrm{~m})$, respectively. The situation is different one day later, when the lower most trajectories are still anticyclonic, but the upper trajectories are cyclonic and originate from Russia. Ensemble trajectories (ca. $1^{\circ}$ lat./long. apart) for the early morning (6 UTC) of 17 March for $2500 \mathrm{~m}$ above ground are also displayed since their arrival time corresponds 


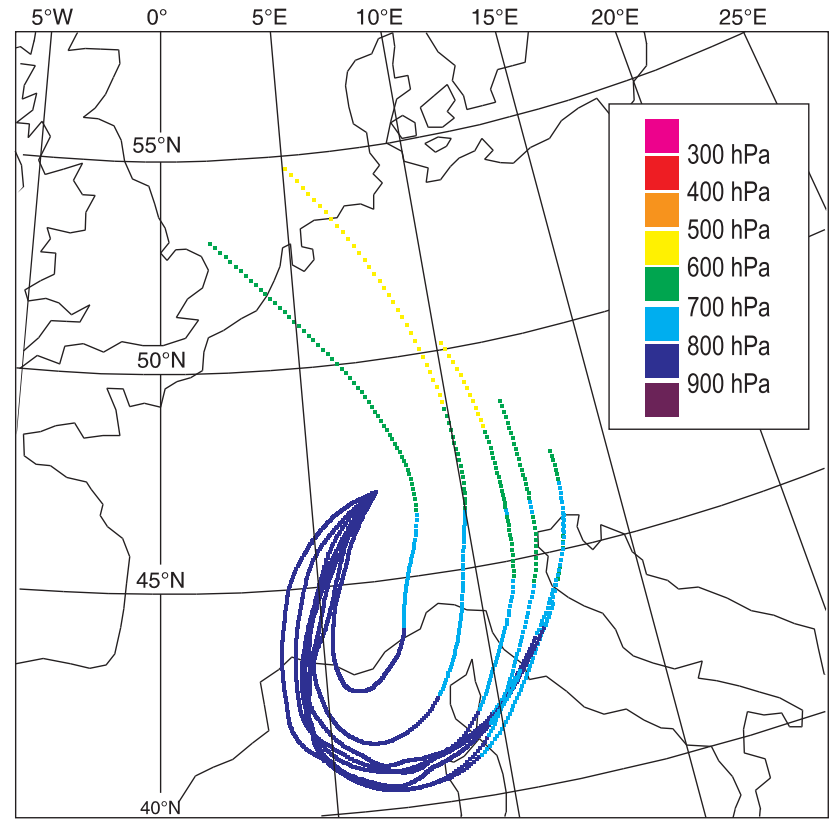

Fig. 10. 72-h backward trajectories from FLEXTRA/ECMWF arriving at Kerzersmoos at the $850 \mathrm{hPa}$ level every 6 hours between 10 February 1998, 18 UTC and 12 February 1998, 12 UTC.

to the time of the high-ozone event at Jungfraujoch. All trajectories come from a zone of horizontal convergence at 600 $\mathrm{hPa}$ over Poland. However, it is very difficult to track the origin of the air masses further back in time. They can originate either from the middle troposphere south of Greenland, the Kola Peninsula or the Ural mountains, or they can originate from the boundary layer of the South-eastern Balkans.

DWD/SM $48 \mathrm{hrs}$ backward trajectories for 17 March, 0 UTC are shown in Fig. 12. Trajectories arrive at different levels at Chaumont, Payerne, and Jungfraujoch and at surrounding points (ensembles of five). All the trajectories slightly descend from their origin towards the receptor site, however, not by large amounts. The lower trajectories arrive from an East-West path along the northern slope of the Alps, whereas a northern component becomes stronger with altitude. At $500 \mathrm{hPa}$ over Payerne, air masses arrive from the North.

\subsubsection{Synoptic analyses for March 1999}

To further study the properties of the advected air mass, we investigated specific humidity from NCEP reanalysis data. Figure 13 displays the field of specific humidity at the 700 hPa level on 17 March, 6 UTC. We see an elongated area of very dry air with its main axis from Poland to Northern Italy, roughly parallel to the trajectories. Values are exceptionally low, down to $0.1 \mathrm{~g} / \mathrm{kg}$. This dry area compares well with the measured humidity minimum of $0.4 \mathrm{~g} / \mathrm{kg}$ at Jungfraujoch. Figure 14 (top) shows station measurements from Zugspitze, which is upwind of the Swiss Plateau. It can be seen that ozone concentrations were also elevated (62
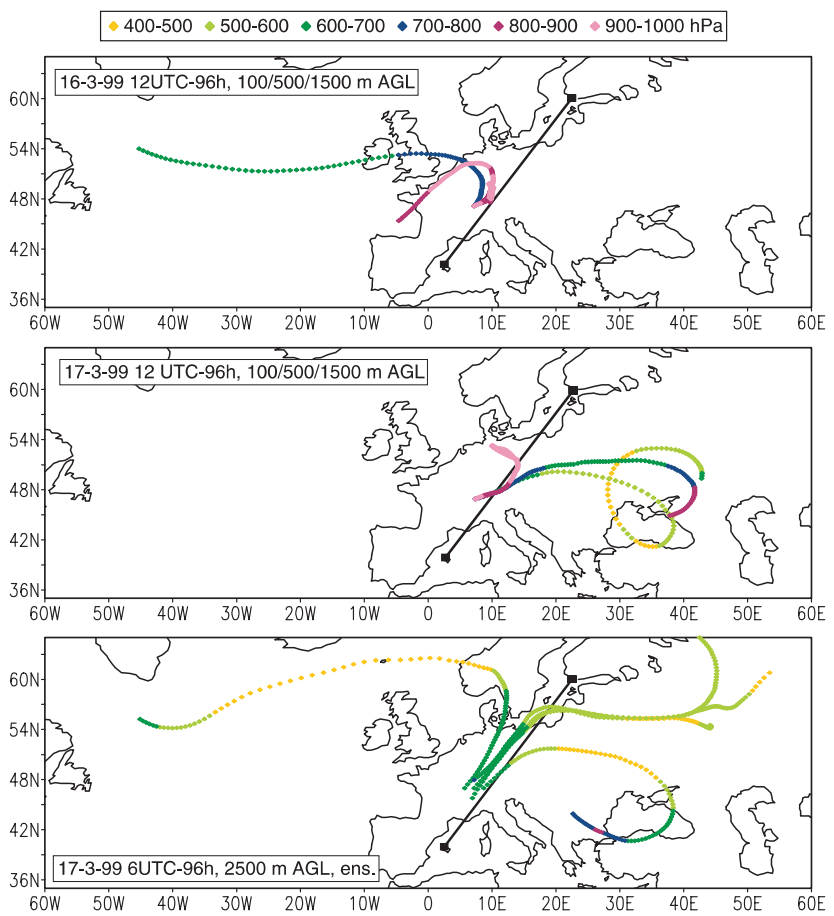

Fig. 11. 96-h backward trajectories from HYSPLIT/FNL arriving at Kerzersmoos at different altitude on 16 March, 12 UTC (top) and on 17 March, 12 UTC (centre), and ensemble of backward trajectories arriving at Kerzersmoos on 17 March, 6 UTC at $2500 \mathrm{~m}$ above ground (bottom). The line indicates the cross section used in Fig. 15.

ppb) on 16 March, in line with a humidity decrease, but they do not show high spikes, such as at Jungfraujoch. A second, stronger humidity decrease down to $13 \%$ was not accompanied by an ozone increase, but occurred at the same time as the ozone spikes at Jungfraujoch.

A number of aerological sounding stations are located close to the trajectories and the dry area shown in Fig. 13. All of them performed ozone soundings on 17 March, 12 UTC, with some already on 15 March, 12 UTC. Figure 14 shows the corresponding humidity and ozone profiles. The profiles show various ozone-rich and dry air layers. For example, a layer with humidity down to $10 \%$ with ozone concentrations of $65 \mathrm{ppb}$ was observed at 2500 to $3000 \mathrm{~m}$ asl over Prague on 15 March. Many smaller scale features were observed in the profiles from 17 March. Ozone was very often, but not always, anticorrelated with humidity in these layers. However, it is not possible to relate these layers to one another or to station measurements. Also, ozone concentrations were always lower than the ones observed at Jungfraujoch (note, again, that the accuracy of ozone sonde measurements in the lower troposphere is not very good). Low ozone concentrations were observed everywhere below $1100 \mathrm{~m}$ asl.

On a somewhat larger scale, a broad picture can be obtained from NCEP reanalysis data. We specified a transect parallel to the trajectories and the dry area (marked in Figs. 11, 12, and 13). Figure 15 shows a temporal (six-hourly) 
$400-500 \square 500-600 \square 600-700 \square 700-800 \square 800-900 \square>900 \mathrm{hPa}$

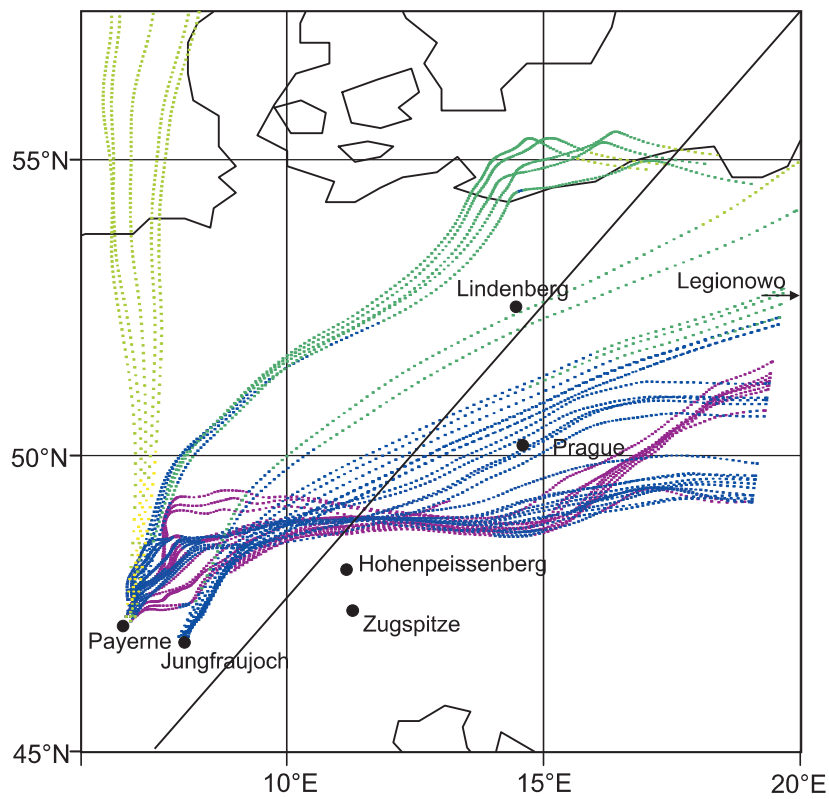

Fig. 12. 48-h backward trajectories (ensembles) from DWD/SM for 17 March, 0 UTC, arriving at Chaumont, Jungfraujoch, and Payerne at various levels. The line indicates the cross section used in Fig. 15. The locations of the sounding sites used in Fig. 14 are also displayed.

series of cross sections of specific humidity along the transect. The $0.25 \mathrm{~g} / \mathrm{kg}$ isoline shows a southward moving and slightly descending tongue of dry air, reaching the Alps on 17 March, 6 UTC. This is again in good agreement with humidity at Zugspitze and Jungfraujoch. The agreement with the soundings is worse at first sight, but is reasonable if one considers the coarse resolution of NCEP data.

From the trajectories, the soundings, and the humidity cross section, it seems plausible that stratospheric or upper tropospheric air has found its way down to the Swiss Plateau. If so, where did this air come from? A glimpse at the continental scale is given in Fig. 16. It shows water vapour images $(5.7-7.1 \mu \mathrm{m})$ from METEOSAT, tropopause pressure from NCEP data, and total ozone from TOMS Version 7 data for 13, 15 and 17 March. Water vapour images show streamers of dry air, most pronounced over Southern France/Corse on 17 March, 12 UTC. They were probably related to the dry air area found in Figs. 14 and 16. Slightly east of this dark area, the tropopause is low, and total ozone reaches 480 DU. These are areas where stratosphere-troposphere exchange can occur. The whole situation evolved from an upper low, north of the Black Sea. It is possible, therefore, that the ozone-rich air parcels hitting the Swiss Plateau were transported on the northern flank of this upper low towards the Alps.

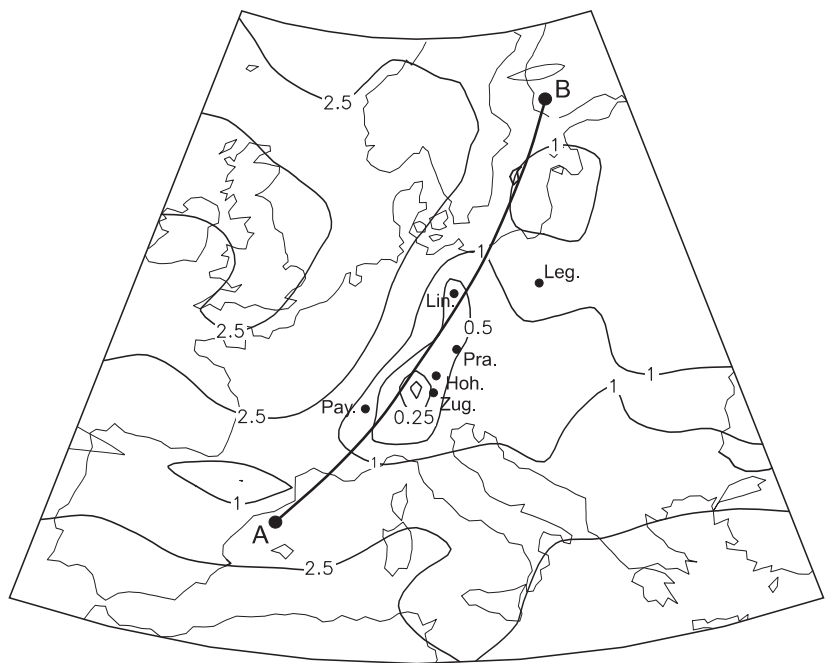

Fig. 13. Specific humidity $[\mathrm{g} / \mathrm{kg}]$ at the $700 \mathrm{hPa}$ level from NCEP/NCAR reanalysis data for 17 March, 6 UTC. The line indicates the cross section used in Fig. 15.

\section{Discussion}

In this section, the results from both episodes are discussed and interpreted and the findings are compared to literature. The most important features for both cases are summarised in Table 1.

\subsection{February 1998}

The February 1998 case can be considered as a typical late winter high-pressure episode with only light winds and high temperatures for the season. Ozone concentrations reached relatively high levels at some elevation above the surface. The pronounced diurnal ozone cycle at the surface was due to a strong ozone sink at the surface (deposition and chemical destruction) in connection with the changing atmospheric stability of the lowest layer, i.e. a small volume and little exchange at night compared to a larger volume and more efficient exchange during the day.

In the morning, the model predicts a slight ozone increase at the surface ( 3 to $5 \mathrm{ppb}$ ) from the reformation of ozone that was titrated during the night. The observed increase of surface ozone during the day, however, was mainly caused by downward mixing of ozone-rich air from aloft. The model predicts only a weak source at the surface during the day, whereas deposition is a strong sink. The downward mixing, on the other hand, was limited by the atmospheric stratification and, therefore, a vertical gradient of the ozone concentration was always maintained.

At around 50 to 800 meters above the ground, photochemical ozone formation provides an ozone source, according to our model using the RACM mechanism. On 11 February, this production was especially strong. In the lowest layers it was probably limited by VOCs, in contrast to summer conditions. A seasonal transition from a $\mathrm{NO}_{x}$ limited photochem- 

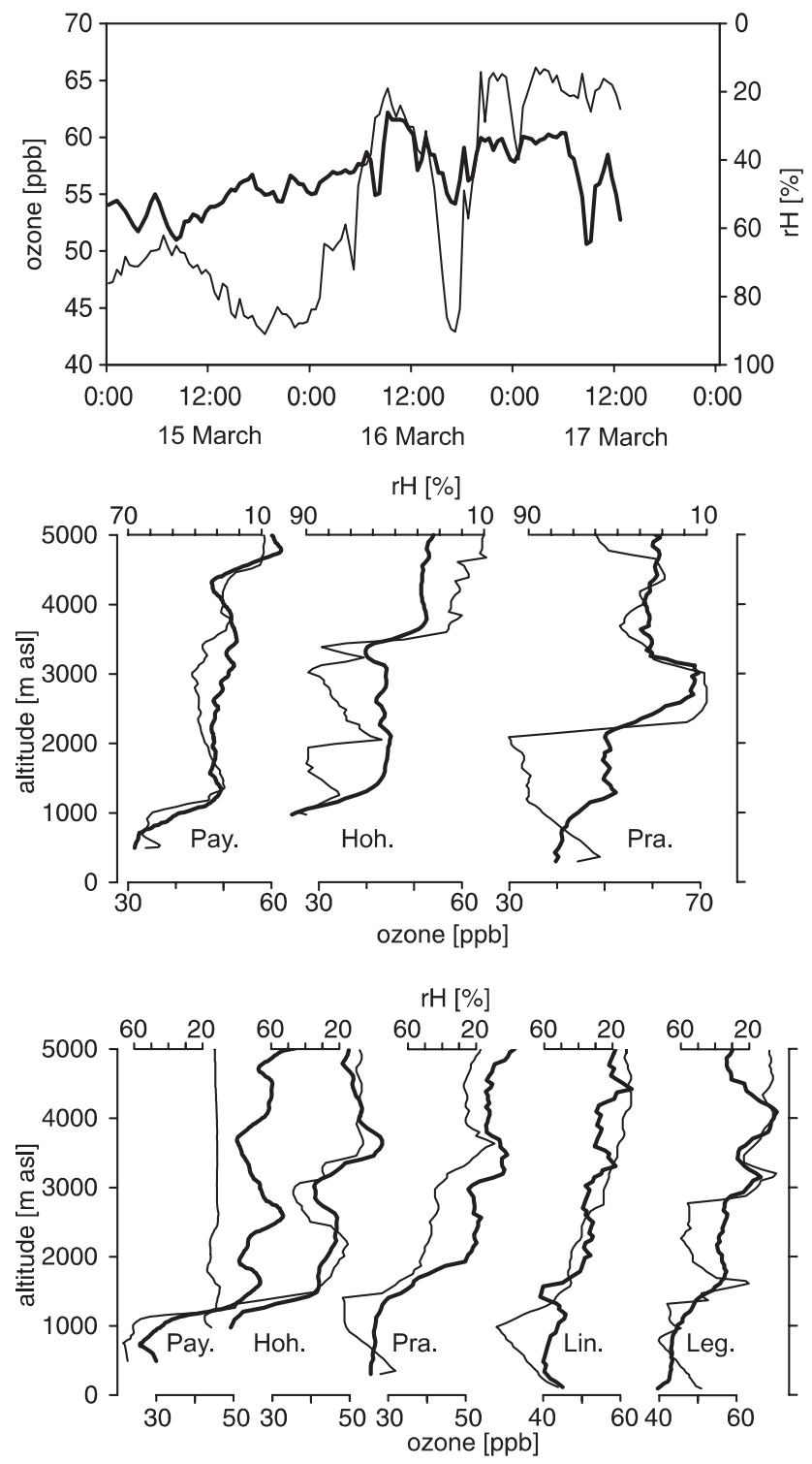

Fig. 14. Measurements of ozone concentration (thick lines) and relative humidity (thin lines) at Zugspitze from 15 to 17 March 1999 (top). The centre and lower panels show ozone and humidity profiles for 15 March, 12 UTC, and 17 March, 12 UTC from different locations in Europe (indicated in Fig. 12). Note that the scale for relative humidity is inverted in all panels.

istry in summer to a VOC limited one in winter was also suggested by Jacob et al. (1995) for the eastern US. The predicted net chemical production rates at $675 \mathrm{~m}$ asl in the early afternoon (Fig. 9f) are roughly 1 to $4 \mathrm{ppb} / \mathrm{h}$ over large parts of the model domain and even 4 to $8 \mathrm{ppb} / \mathrm{h}$ in plumes (note that this number includes titration and reformation of titrated ozone on time scales longer than 2 hours). This is considerable, but much less than in summer, for which typical values of 6 to $10 \mathrm{ppb} / \mathrm{h}$ were estimated (Neininger and Dommen, 1996, see also Jenkin and Clemitshaw, 2000). This net source is largely compensated by the chemical surface sink and by deposition. Since locally controlled boundary-layer
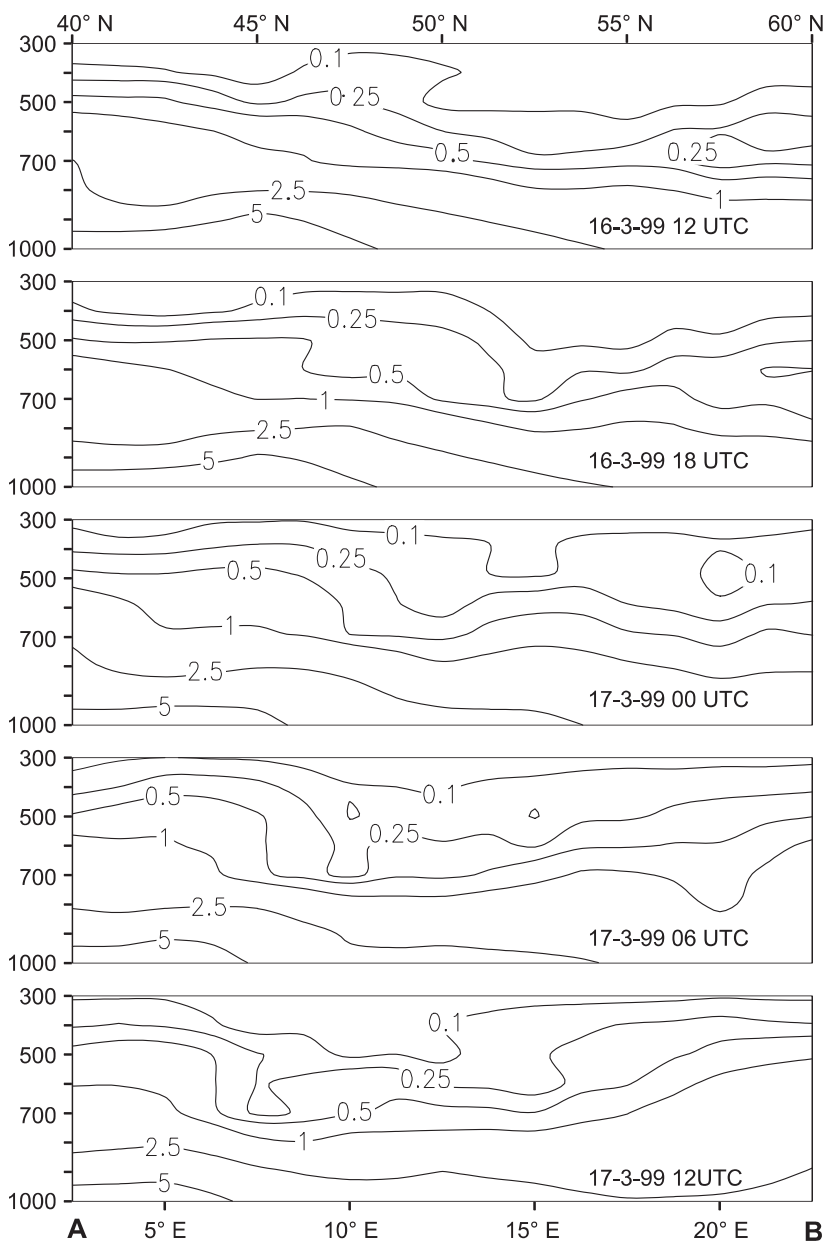

Fig. 15. Series of cross sections of specific humidity $[\mathrm{g} / \mathrm{kg}]$ along the line indicated in Figs. 11 to 13 from the surface to the $300 \mathrm{hPa}$ level from NCEP/NCAR reanalysis data.

processes determine the extent of the corresponding downward flux, and since horizontal transport was weak, we can address this layer as a local layer.

The main ozone source for the lower layers was the downward mixing of ozone from an upper layer at about 1000 to $1200 \mathrm{~m}$ asl, where high ozone concentrations (50 to $60 \mathrm{ppb}$ ) were measured. Dynamically, the specific situation above the "cold" or "local" layer on the Swiss Plateau but below the altitude of the geostrophic wind could have played a role in the formation of this layer under a high pressure situation. But how did the ozone come in? Downward mixing cannot have contributed significantly since the vertical ozone gradient was small or even reversed. At this altitude, a net chemical source is predicted by the model. Furthermore, areas of high net chemical ozone production are simulated along the slope of the first Jura mountain ridge $(\sim 4 \mathrm{ppb} / \mathrm{h})$, with pollutants from the major motorway A1 transported upwards by slope winds. This mechanism was already suggested for summer during the POLLUMET campaigns (Neininger and Dommen, 1996). The diurnal cycles of $\mathrm{NO}, \mathrm{NO}_{2}$ and ozone at Chaumont point to such a slope transport, although weaker 

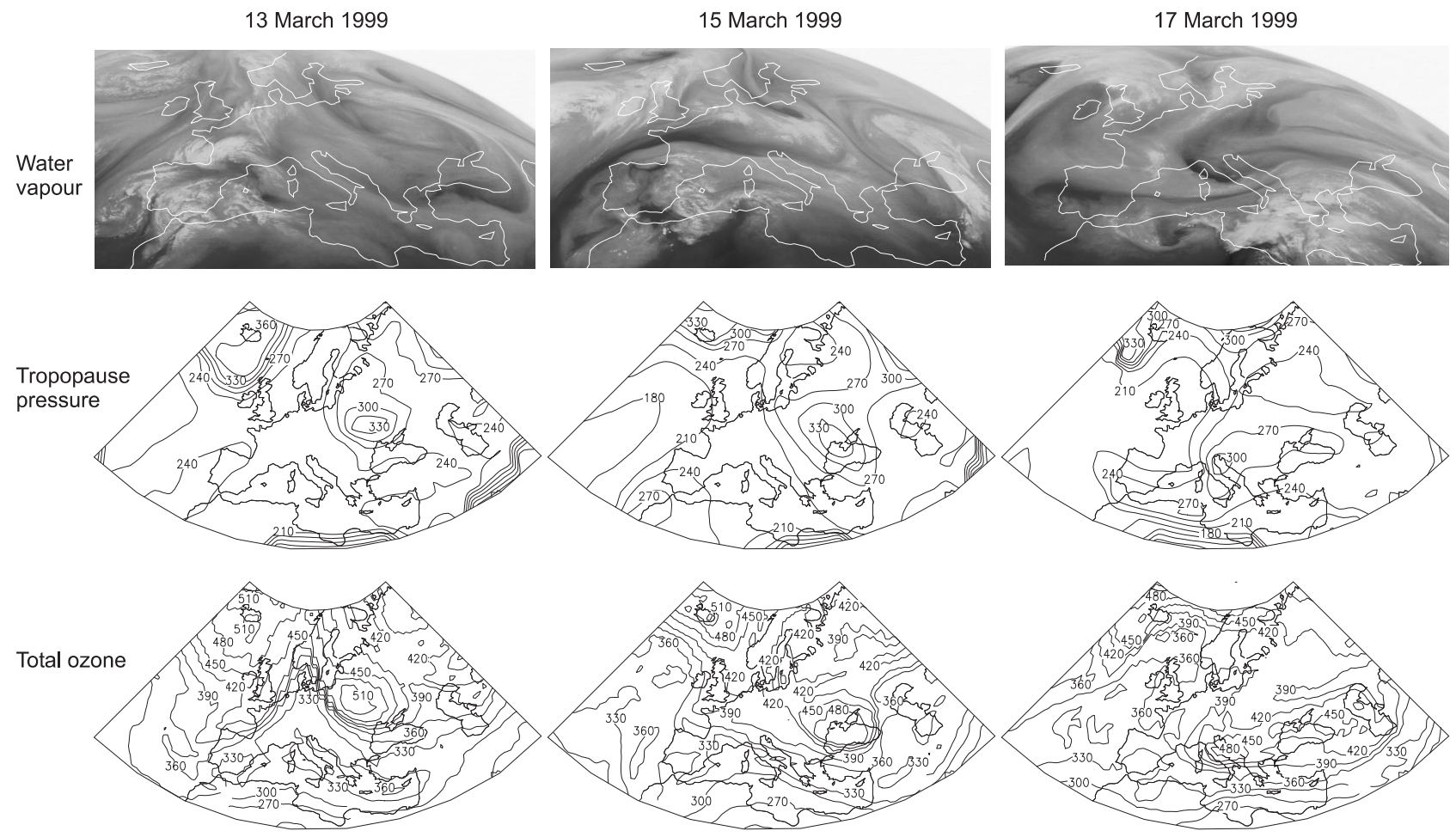

Fig. 16. Meteosat water vapour images from EUMETSAT (top; dry air is black), tropopause height at 12 UTC from NCEP/NCAR data (centre, units are hPa), and Earth Probe TOMS Version 7 total ozone data (in DU) for 13, 15, and 17 March 1999 (C) EUMETSAT.

than in the model calculations (Fig. 7). Some of the ozone or its precursors could have been injected into the stable layer by slope transport (see also McKendry and Lundgren, 2000).

Besides in situ chemical formation, another influence on ozone concentration in this layer was horizontal transport. Air masses were probably advected at an altitude of about $850 \mathrm{hPa}$ within a jet over Kerzersmoos on 11 February. Several ozone sources are possible. First, downward transport of ozone-rich air from the middle troposphere over northern and central Europe to around $850 \mathrm{hPa}$ over Italy and quasihorizontal transport to Kerzersmoos could be one cause. An argument against this origin is that Jungfraujoch displayed lower ozone values than Chaumont throughout the episode and that it took at least 3 to 4 days until the air masses reached Kerzersmoos. Air masses probably have spent a large fraction of this time in or close to the boundary layer. It seems plausible that ozone has been formed during the last two days before arrival. The ozone-rich layer observed at Kerzersmoos could be a "residual layer" from photochemical ozone formation on the days before, over the Rhone Valley, Southern France, or the Mediterranean Sea, where radiation is higher (NOAA satellite images show that the trajectories were within cloudless areas most of the time). This layer was possibly advected above the "local" layer. This kind of transport was suggested to play a role for the vertical ozone distribution at Payerne in a statistical framework (Jeannet et al., 1996). From the POLLUMET studies it was suggested that the contribution of this "reservoir ozone" to observed summer ozone peaks is around $30 \mathrm{ppb}$ (Neininger and Dommen,
1996). A case study of advection of an ozone-rich "residual layer" from the previous day's boundary layer over the Po Valley (Northern Italy), over a locally trapped cold air layer in southern Switzerland and subsequent downward mixing in the morning has been presented by Prévôt et al. (2000).

Above the jet and above the ozone-rich layer, ozone and humidity were fairly constant with time. This air was probably not in contact with the boundary layer for the last few days, and in situ chemical ozone production was slow.

\subsection{March 1999}

The March 1999 campaign represents completely different meteorological conditions than the February 1998 campaign; it was a strong "Bise" situation that followed a short and moderate ozone episode. At the beginning, local influences, such as a strong sink at the surface and downward mixing during the day, were again dominant in determining the ozone variability at the surface. However, the north-easterly winds increased in strength and their influence soon dominated over the local influences. No stable surface layer could develop during the third night (16/17 March) due to strong winds, and transport of ozone from aloft was facilitated. Additionally, daytime ozone concentrations decreased during these three days, below about $1200 \mathrm{~m}$ asl, despite sunny weather and a corresponding potential for chemical ozone production. This was probably due to advection of ozone-poor air, as is also suggested by upwind soundings (Fig. 14). Above the well mixed, humid and ozone-poor boundary layer with the top 
Table 1. Main characteristics of the two ozone episodes, dominating processes governing the ozone variability, and involved spatial scales at three altitudes

\begin{tabular}{|c|c|c|}
\hline & 11 Feb 1998 & 17 Mar 1999 \\
\hline \multicolumn{3}{|l|}{ surface } \\
\hline $\begin{array}{l}\text { ozone maximum } \\
\text { processes }\end{array}$ & $\begin{array}{l}35 \mathrm{ppb} \\
\text { surface sink, } \\
\text { downmixing }\end{array}$ & $\begin{array}{l}35 \mathrm{ppb} \\
\text { surface sink, } \\
\text { advection }\end{array}$ \\
\hline scale of influence & local & mesoscale \\
\hline $\begin{array}{l}1000 \mathrm{~m} \text { asl } \\
\text { ozone maximum } \\
\text { processes }\end{array}$ & $\begin{array}{l}60 \mathrm{ppb} \\
\text { in situ chemistry, } \\
\text { advection }\end{array}$ & $\begin{array}{l}60 \mathrm{ppb} \\
\text { advection }\end{array}$ \\
\hline scale of influence & mesoscale & large-scale \\
\hline $\begin{array}{l}3500 m \text { asl } \\
\text { ozone maximum } \\
\text { processes }\end{array}$ & $\begin{array}{l}50 \mathrm{ppb} \\
\text { background } \\
\text { chemistry }\end{array}$ & $\begin{array}{l}80 \mathrm{ppb} \\
\text { stratospheric } \\
\text { intrusion? }\end{array}$ \\
\hline scale of influence & large-scale & large-scale \\
\hline
\end{tabular}

extending to around $900 \mathrm{~m}$ asl, a distinctly different air mass was observed.

With respect to ozone, the most important feature was a dry and ozone-rich (up to $60 \mathrm{ppb}$ ) air parcel that was observed with the kite on 17 March above the boundary layer; one of many such air parcels that were observed at that time over different sites in Europe. At Chaumont, at about the same height, humid air with low ozone concentrations was observed. Wind measurements reveal that Chaumont was influenced by up-slope winds and thus, was still sampling air from the mixed layer. The Payerne sounding ( 2 hours later) showed high ozone concentrations at about 1700 and $2700 \mathrm{~m}$ asl. At Jungfraujoch, $81 \mathrm{ppb}$ of ozone were measured during a very short time of about one hour, and the relative humidity dropped below 10\%. Soundings from other European sites and station data from Zugspitze reveal several dry and mostly ozone-rich air parcels, but it is not possible to relate these dry air parcels to one another.

There is a possible chemical explanation for an anticorrelation between humidity and ozone, namely that photochemical ozone destruction ( $\mathrm{OH}$ formation) is suppressed with low humidity. However, this mechanism, taking place further north, is probably far too slow to produce large concentration differences in a reasonably short time, such as in our case.

The air parcels originated from a convergence zone in the middle troposphere over Poland. The NCEP reanalysis data are not able to resolve the air parcels, but show them as a tongue of dry air that extended from north-eastern Europe towards the Alps during these days.

The small spatial extent and the spiky behaviour of the peaks, as well as the simultaneous low humidity points to an upper tropospheric or lower stratospheric source for this ozone. This is in agreement with trajectories. If we further speculate on the location of the stratosphere-troposphere exchange, advection from Russia would go back to an upper low, where stratosphere-troposphere exchange could have taken place. This is supported by an analysis of water vapour images and total ozone fields.

Although this last point remains uncertain, it can be stated that several dry and ozone-rich air parcels of possibly stratospheric or upper tropospheric origin entered the middle and lower free troposphere over Central Europe. It seems even plausible that the air parcel sampled with the kite at Kerzersmoos above $1000 \mathrm{~m}$ asl was of stratospheric or upper tropospheric origin.

\section{Conclusions}

Two detailed case studies were performed to analyse the influences of different mechanisms on the ozone profile over Kerzersmoos on the Swiss Plateau in early spring. In both cases, high ozone concentrations were found, but they were contrasting with respect to the meteorological situation. Individual processes could be addressed with the help of measurements and modelling.

The results indicate that early spring ozone peaks or elevated high-ozone layers over the Swiss Plateau can have different causes. Advection of ozone is certainly important. This holds for photochemically formed ozone from the boundary layer of more southerly countries, where the radiation is larger, as well as for upper tropospheric or stratospheric air parcels that are advected from the north or northeast over the Swiss Plateau.

Perhaps most surprisingly, a substantial influence of in situ photochemical ozone formation is indicated by model calculations already for February for the layers above the surface. The calculated net chemical production rate at noon amounts to 1 to $4 \mathrm{ppb} / \mathrm{h}$, on average, on the Swiss Plateau and even more in plumes. Thus, if the RACM chemical mechanism is applicable also in late winter (our validation seems to confirm this), chemical ozone episodes are not unrealistic during persistent high-pressure situations.

This study demonstrates that the altitude range of about 900 to $1300 \mathrm{~m}$ asl is very important for the understanding of ozone dynamics in early spring (see also McKendry and Lundgren, 2000). It can participate in photochemical ozone formation, storage, and transport, as was already suggested in a climatological framework (Brönnimann, 1999).

Finally, the study shows the great potential of routine data and freely available software for detailed case studies.

Acknowledgements. S. B. is funded by the Swiss Agency for Environment, Forests, and Landscape (SAEFL) under contract FE/BUWAL/810.98.7. F. S. was supported by the Swiss National Science Foundation, grants SNF 21-42050.94 and 20-50532.97. W. E. was supported by the Hans-Sigrist Foundation from the University of Bern. C. S. was funded by the Swiss Commission on Technology and Innovation, grants KTI 3535.1 and 4136.1. Tethered balloon soundings were performed within the framework of the SNF-funded BAT project components. NABEL measurements 
were provided by SAEFL, additional CO measurements by EMPA. MeteoSwiss provided us with meteorological data from Jungfraujoch, the aerological sounding data from Payerne, and backward trajectories. HYSPLIT trajectories were calculated on the web site of NOAA (www.arl.noaa.gov/ready/traj4.html). We wish to thank H. Claude and D. Horst (DWD), P. Skrivankova (Czech Hydrometeorological Institute) and Z. Litynska (Legionowo) for providing us with sounding data from Hohenpeissenberg, Lindenberg, Prag, and Legionowo, respectively. Station data from Zugspitze were provided and prepared by W. Seiler and H.-E. Scheel. We would like to thank all volunteer helpers during our field campaigns at Kerzersmoos. The Metphomod model can be downloaded, along with the documentation and the input data used for this study from: http://www.giub.unibe.ch/klimet/metphomod/

Topical Editor J. P. Duvel thanks two referees for their help in evaluating this paper.

\section{References}

Aneja, V. P., Arya, S. P., Li, Y., Murray, G. C. Jr., and Manuszak, T. L., Climatology of diurnal trends and vertical distribution of ozone in the atmospheric boundary layer in urban North Carolina, J. Air \& Waste Manage. Assoc., 50, 54-64, 2000.

Baumbach, G., Baumann, K., Grauer, A., Semmler, R., Steisslinger, B., Wanner, H., Künzle, T., and Neu, U., A tethersonde measuring system for detection of $\mathrm{O}_{3}, \mathrm{NO}_{2}$, hydrocarbon concentrations and meteorological parameters in the lower boundary layer, Meteorol. Z., N. F. 2, 178-188, 1993.

Brönnimann, S., Early spring ozone episodes: Occurrence and case study, Phys. Chem. Earth, 24C, 531-536, 1999.

Cattin, R., Field phase report of the Tethered Balloon Soundings (BAT), Kerzersmoos, 8-12 February 1998, Institute of Geography, University of Bern, 1998.

Cattin, R., Field phase report of the Tethered Balloon Soundings (BAT), Kerzersmoos, 15-17 March 1999, Institute of Geography, University of Bern, 1999.

Corsmeier, U., Kalthoff, N., Kolle, O., Kotzian, M., and Fiedler, F., Ozone concentration jump in the stable nocturnal boundary layer during a LLJ-event, Atmos. Environ., 31, 1977-1989, 1997.

Crutzen, P. J., Lawrence, M. G., and Pöschl, U., On the background photochemistry of tropospheric ozone, Tellus, 51AB, 123-146, 1999.

Dommen, J., Neftel, A., Sigg, A., and Jacob, D. J., Ozone and hydrogen peroxide during summer smog episodes over the Swiss Plateau: Measurements and model simulations, J. Geophys. Res., 100, 8953-8966, 1995.

Dommen, J., Prévôt, A. S. H., Hering, A. M., Staffelbach, T., Kok, G. L., and Schillawski, R. D., Photochemical production and aging of an urban air mass, J. Geophys. Res., 104, 5493-5506, 1999.

Draxler, R. R. and Hess, G. D., Description of the Hysplit-4 modeling system, NOAA Tech Memo ERL ARL-224, 1997.

Draxler, R. R. and Hess, G. D., An overview of the Hysplit-4 modeling system for trajectories, dispersion, and deposition, Aust. Met. Mag., 47, 295-308, 1998.

ECMWF, The description of the ECMWF/WCRP Level III-A Global Atmospheric Data Archive, ECMWF, 1994.

EMPA (Swiss Federal Laboratories for Materials Testing and Research), Technischer Bericht zum Nationalen Beobachtungsnetz für Luftfremdstoffe (NABEL) 1994. Dübendorf, 1994.

Eugster, W., Perego, S., Wanner, H., Leuenberger, A., Liechti, M.,
Reinhard, M., Geissbühler, P., Gempeler, M., and Schenk, J., Spatial variation in annual nitrogen deposition in a rural region in Switzerland, Environmantal Pollution, 102, S1, 327-335, 1998.

Fay, B., Glaab, H., Jacobsen, I., and Schrodin, M., Radioactive dispersion modelling and emergency response system at the German Weather Service, in: S.-V. Gryning and M. M. Millan (Eds.), Air pollution modelling and its application X, Plenum Press, New York, 1994.

Fiedler, F. and Borrell, P., TRACT: Transport of air pollutants over complex terrain, in: P. Borrell and P. M. Borrell (Eds.), Transport and chemical transformation of pollutants in the troposphere, Vol. 1, pp. 239-283, Springer, Berlin, Heidelberg, New York, 2000.

Furger, M., Die Radiosondierungen von Payerne - Dynamischklimatologische Untersuchungen zur Vertikalstruktur des Windfeldes, $\mathrm{PhD}$ thesis, 192 pp, Lenticularis, Opfikon, 1990.

Furger, M., Dommen, J., Graber, W. K., Pioggio, L., Prévôt, A. S. H., Emeis, S., Greill, G., Trickl, T., Gomiscek, B., Neininger, B., and Wotawa, G., The VOTALP Mesolcina Campaign $1996-$ concept, background and some highlights, Atmos. Environ., 34, 1395-1412, 2000

Hidy, G. M., Ozone process insights from field experiments, Part I: overview, Atmos. Environ., 34, 2001-2022, 2000.

Jacob, D. J., Horowitz, L. W., Munger, J. W., Heikes, B. G., Dickerson, R. R., Artz, R. S., and Keene, W. C., Seasonal transition from $\mathrm{NO}_{x}$ - to hydrocarbon-limited conditions for ozone production over the eastern United States in September, J. Geophys. Res., 100, 9315-9324, 1995.

Jacob, D. J., Logan, J. A., and Murti, P. P., Effect of rising Asian emissions on surface ozone in the United States, Geophys. Res. Lett., 26, 2175-2178, 1999.

Jeannet, P., Hoegger, B., and Viatte, P., Vertical mixing and horizontal advection of ozone over the Swiss Plateau during summer smog episodes, in: BUWAL (Ed.), Proceedings of EMEP Workshop on the control of photochemical oxidants over Europe, Environmental documentation No. 47, pp 111-114, Bern, 1996.

Jenkin, M. E. and Clemitshaw, K. C., Ozone and secondary photochemical pollutants: chemical processes governing their formation in the planetary boundary-layer, Atmos. Environ., 34, 2499 2527, 2000.

Kalnay, E. et al., The NCEP/NCAR 40-year reanalysis project, Bull Am. Meteorol. Soc., 77, 437-471, 1996.

Kunz, S., Künzle, T., and Rihm, B., TRACT Emissionsmodell Schweiz, Technical Report, Meteotest, Bern, 1995.

Künzle, T. and Neu, U., Experimentelle Studien zur räumlichen Struktur und Dynamik von Sommersmog über dem Schweizerischen Mittelland, Geographica Bernensia, Bern, 1994.

Madronich, S., Zeng, J., and Stamnes, K., Tropospheric ultravioletvisible radiation model, Version 3.9a, February 1997.

McElroy, J. L. and Smith, T. B., Creation and fate of ozone layers aloft in Southern California, Atmos. Environ., 27A, 1917-1929, 1993.

McKendry, I. G., Steyn, D. G., Lundgren, J., Hoff, R. M., Strapp, W., Anlauf, K., Froude, F., Martin, J. B., Banta, R. M., and Olivier, L. D., Elevated ozone layers and vertical down-mixing over the Lower Fraser Valley, BC, Atmos. Environ., 31, 21352146, 1997.

McKendry, I. G. and Lundgren, J., Tropospheric layering of ozone in regions of urbanized complex and/or coastal terrain: a review, Progress in Physical Geography, 24, 329-354, 2000.

McPeters, R. D. et al., Earth Probe Total ozone mapping spectrometer (TOMS) data products user guide, NASA Technical Publica- 
tion 1998-206895, NASA/Goddard Space Flight Centre, Greenbelt MD, 1998 .

Monks, P., A review of the observations and origins of the spring ozone maximum, Atmos. Environ., 34, 3545-3561, 2000.

Neininger, B. and Dommen, J., POLLUMET, Luftverschmutzung und Meteorologie in der Schweiz, Ed. BUWAL, Umweltmaterialien Nr. 83, 282 pp, Bern, 1996.

Neu, U., Künzle, T., and Wanner, H., On the relation between ozone storage in the residual layer and daily variation in near-surface ozone concentration - a case study, Boundary-Layer Meteorol., 69, 221-247, 1994.

Parrish, D. D., Ryerson, T. B., Holloway, J. S., and Fehsenfeld, F. C., Does pollution increase or decrease tropospheric ozone in Winter-Spring? Atmos. Environ., 33, 5147-5149, 2000.

Perego, S., Metphomod - a numerical mesoscale model for simulation of regional photosmog in complex terrain: Model description and application during Pollumet 1999 (Switzerland), Met. Atmos. Phys., 70, 43-70, 1999.

Prévôt, A. S. H., Photooxidantion und Primärluftschadstoffe in der planetaren Grenzschicht nördlich und südlich der Alpen, PhD thesis, Diss. ETH Nr. 10956, 126 pp, Zürich, 1994.

Prévôt, A. S. H., Dommen, J., Bäumle, M., and Furger, M., Diurnal variations of volatile organic compounds and local circulation systems in an alpine valley, Atmos. Environ., 34, 1413-1423, 2000.

Richner, H. and v. Hünerbein, S. (Eds.), Grundlagen aerologischer Messungen speziell mittels der Schweizer Sonde SRS 400, Veröffentlichungen der SMA-MeteoSchweiz Nr. 61, 140 pp, Zürich, 1999.

Ryan, W. R., Doddridge, B. G., Dickerson, R. R., Morales, R. M., Hallock, K. A., Roberts, P. T., Blumenthal, D. L., Anderson, J. A., and Ciccerolo, K. L., Pollutant transport during a regional $\mathrm{O}_{3}$ episode in the mid-atlantic states, J. Air \& Waste Manage. Assoc., 48, 786-797, 1998.

Seibert, P., Feldmann, H., Neininger, B., Bäumle, M., and Trickl, T., South foehn and ozone in the Eastern Alps - case study and climatological aspects, Atmos. Environ., 34, 1379-1394, 2000.

Schere, K. L. and Hidy, G. M., NARSTO critical reviews (Foreword), Atmos. Environ., 34, 1853-1860, 2000.

Shetter, R. E. et al., Actinometric and radiometric measurements and modeling of the photolysis rate coefficient of ozone to $\mathrm{O}\left({ }^{1} D\right)$ during Mauna Loa Observatory Photochemistry Experiment 2, J. Geophys. Res., 101, 14631-14641, 1996.

Schubiger, F. and de Morsier, G., Erstellung von Anfangs- und Randfeldern für das hochauflösende Regionalmodell (HRM) und dazugehörige Experimente, Arbeitsberichte der Schweizerischen Meteorologischen Anstalt, No. 169, 34 pp, Zürich, 1992.

Schuepbach, E., Davis, T. D., Massacand, A. C., and Wernli, H., Mesoscale modelling of vertical atmospheric transport in the Alps associated with the advection of a tropopause fold - a winter ozone episode, Atmos. Environ., 33, 3613-3626, 1999.

Siegrist, F., Determination of energy and trace gas fluxes on a regional scale, Combination of local surface flux measurements and vertical flux profiles throughout the Atmospheric Boundary in complex terrain, $\mathrm{PhD}$ thesis, Geographica Bernensia, Bern (in press).

Sillman, S., The use of $\mathrm{NO}_{y}, \mathrm{H}_{2} \mathrm{O}_{2}$, and $\mathrm{HNO}_{3}$ as indicators for ozone- $\mathrm{NO}_{x}$-hydrocarbon sensitivity in urban locations, J. Geophys. Res., 100, 14175-14188, 1995.

Solomon, P., Cowling, E., Hidy, G., and Furiness, C., Comparison of scientific findings from major ozone field studies in North America and Europe, Atmos. Environ., 34, 1885-1920, 2000.

Staffelbach, T. and Neftel, A., Relevance of biogenically emitted trace gases for the ozone production in the planetary boundary layer in Central Europe, Schriftenreihe der FAL Nr. 25, Zürich, 1997.

Stockwell, B., Kirchner, F., Kuhn, M., and Seefeld, S., A new mechanism for regional atmospheric chemistry modeling, J. Geophys. Res., 102, 25847-25879, 1997.

Stohl, A. and Trickl, T., A textbook example of longe-range transport: Simultaneous observations of ozone maxima of stratospheric and North American origin in the free troposphere over Europe, J. Geophys. Res., 104, 30445-30462, 1999.

Stohl, A., Wotawa, G., Seibert, P., and Kromp-Kolb, H., Interpolation errors in wind fields as a function of spatial and temporal resolution and their impact on different types of kinematic trajectories, J. Appl. Meteor., 34, 2149-2165, 1995.

Stübi, R., Ammann, C., Ruffieux, D., Bretz, N., Viatte, P., Levrat, G., Hoegger, B., Schmidlin, F. J., Brothers, G., Michel, W., and Moore, P., BM-ECC ozone twin flights: differences between two ozone sonde types, in Proceedings of Fifth European Workshop on stratospheric ozone, St.-Jean de Luz, 4 pp, 1999.

Stübi, R., Ammann, C., Ruffieux, D., Levrat, G., Hoegger, B., and Viatte, P., Comparability between BM and ECC ozone sondes, in: NASDA (Ed.), Proceedings of the Quadrennial Ozone Symposium, Sapporo, pp. 657-658, 2000.

Stunder, B. J. B., NCEP Model Output - FNL ARCHIVE DATA, TD-6141 Prepared for National Climatic Data Center (NCDC), NOAA-Air Resources Laboratory, Silver Spring, MD, 1997.

Wakamatsu, S., Uno, I., and Ohara, T., Springtime photochemical air pollution in Osaka: Field observation, J. Appl. Met., 37, 1100-1106, 1998

Wanner, H. and Furger, M., The Bise - Climatology of a regional wind north of the Alps, Meteorol. Atmos. Phys., 43, 105-115, 1990.

Wanner, H., Künzle, T., Neu, U., Ihly, B., Baumbach, G., and Steisslinger, B., On the dynamics of photochemical smog over the Swiss Middleland - results of the first POLLUMET field experiment, Meteorol. Atmos. Phys., 51, 117-138, 1993.

Whiteman, C. D., Mountain meteorology - Fundamentals and applications, Oxford University Press, New York, 2000.

Wotawa, G. and Kromp-Kolb, H., The research project VOTALP general objectives and main results, Atmos. Environ., 34, 13191322, 2000.

Wotawa, G., Kröger, H., and Stohl, A., Transport of ozone towards the Alps - results from trajectory analyses and photochemical model studies, Atmos. Environ., 34, 1367-1377, 2000.

Wunderli, S. and Gehrig, R., Influence of temperature on formation and stability of surface PAN and ozone, A two year field study in Switzerland, Atmos. Environ., 25A, 1599-1608, 1991. 